\title{
Endocrine disruption of oestrogen action and female reproductive tract cancers
}

\author{
Douglas A Gibson and Philippa T K Saunders \\ Queen's Medical Research Institute, MRC Centre for Reproductive Health, The University of Edinburgh, \\ 47 Little France Crescent, Edinburgh EH16 4TJ, UK
}

Correspondence should be addressed to D A Gibson Email d.a.gibson@ed.ac.uk

\begin{abstract}
Endocrine disrupting chemicals (EDC) are ubiquitous and persistent compounds that have the capacity to interfere with normal endocrine homoeostasis. The female reproductive tract is exquisitely sensitive to the action of sex steroids, and oestrogens play a key role in normal reproductive function. Malignancies of the female reproductive tract are the fourth most common cancer in women, with endometrial cancer accounting for most cases. Established risk factors for development of endometrial cancer include high BMI and exposure to oestrogens or synthetic compounds such as tamoxifen. Studies on cell and animal models have provided evidence that many EDC can bind oestrogen receptors and highlighted early life exposure as a window of risk for adverse lifelong effects on the reproductive system. The most robust evidence for a link between early life exposure to EDC and adverse reproductive health has come from studies on women who were exposed in utero to diethylstilbestrol. Demonstration that EDC can alter expression of members of the HOX gene cluster highlights one pathway that might be vulnerable to their actions. In summary, evidence for a direct link between EDC exposure and cancers of the reproductive system is currently incomplete. It will be challenging to attribute causality to any single EDC when exposure and development of malignancy may be separated by many years and influenced by lifestyle factors such as diet (a source of phytoestrogens) and adiposity. This review considers some of the evidence collected to date.
\end{abstract}
Key Words
- endocrine disruptor
- endocrine disrupting chemical
- oestrogen receptor
- reproductive cancer
- endometrial cancer
- obesity
- diethylstilbestrol
- bisphenol A
- dioxin
- phytoestrogen
- genistein
- HOX genes

\section{Introduction}

The tissues of the female reproductive tract (vagina, cervix, uterus and fallopian tube) are key targets for the action of oestrogens by virtue of their expression of oestrogen receptors (ERs). During a woman's reproductive years, these tissues are subjected to cyclical variations in circulating concentrations of endogenous oestrogens that are synthesised and secreted by the ovarian follicles during natural menstrual cycles. Malignancies of the female reproductive tract are the fourth most common cancer in women (http://www.cancerresearchuk.org/ cancer-info/cancerstats/incidence/commoncancers/ uk-cancer-incidence-statistics-for-common-cancers\#Top3; accessed August 2013). Endometrial cancer accounts for the majority of these cancers, although cervical and vaginal tissues are also susceptible to neoplastic transformation (Doll et al. 2008). Cancer of the fallopian tube is very rare (Alvarado-Cabrero et al. 2013). Recently, emerging evidence has indicated that cells located in the

\footnotetext{
Published by Bioscientifica Ltd.

This paper is one of three papers that form part of a thematic review section on

Endocrine Disruptors and Sancer. The guesteditor for this section was Gail Ristoridger $0: 36: 49 \mathrm{AM}$

Monash University, Australia
via free access
} 
fimbrial end of the fallopian tube may hold the key to development of some forms of cancers previously thought to be ovarian in origin (Dubeau 2008, Flesken-Nikitin et al. 2013).

Endocrine disrupting chemicals (EDC) are compounds that are known to interfere with normal hormone signalling and action. The most significant EDC are environmental pollutants or major constituents of preservatives and industrial plasticizers. Approximately 800 chemicals are known or suspected to have the potential to function as EDC (Bergman et al. 2013).

The effects of EDC on reproductive health of animals have been widely reported and animal models have been used to inform studies on the consequences of human exposure. For example, decreased fertility has been reported in fish and birds and feminisation of male fish, birds and mammals exposed to EDC in the environment documented (reviewed in Colborn et al. (1993)). Notably, early life exposure has been identified as a key window of susceptibility for development of disorders of the female reproductive system in both animals and humans (see reviews by Miller et al. (2004) and Crain et al. (2008)).
EDC can have pleiotropic action throughout the body with effects being mediated via disruption of steroidhormone-dependent signalling; in addition to effects on the reproductive system, some EDC are reported to have the potential to interfere with neuroendocrine regulation, adiposity, metabolism and the immune system (Newbold et al. 2005, Ponzo \& Silvia 2013). A summary of the steroid receptor targets of a selection of widely studied EDC are presented in Table 1. It is notable that some EDC such as bisphenol A (BPA) are promiscuous in their action and have activity at several hormone receptors that may complicate interpretation of their precise role(s) in the development of malignancy.

Although exposure to EDCs has been suggested as a contributing factor to a range of women's health disorders including infertility, polycystic ovaries, uterine fibroids and the early onset of puberty, considerable challenges remain in attributing cause and effect (reviewed in Crain et al. (2008)). In this review, we consider the evidence that exposure to EDCs can increase the lifetime risk of developing a reproductive tract cancer and the mechanisms that might be responsible for their effects.

Table 1 Pleiotropic endocrine disrupting effects of major EDCs and their reported effect on nuclear hormone receptors

\begin{tabular}{|c|c|c|c|c|}
\hline EDC & ER & AR & Other nuclear receptors & References \\
\hline DES & Agonist & Weak binding affinity & $\begin{array}{l}\text { Inverse agonist of ERR } \alpha \text {, } \\
\text { ERR } \beta \text { and ERR } \gamma\end{array}$ & $\begin{array}{l}\text { Kuiper et al. (1998) and } \\
\text { Giguere (2002) }\end{array}$ \\
\hline BPA & Agonist & Anti-androgen & $\begin{array}{l}\text { Strong binding affinity } \\
\text { to ERR } \gamma \\
\text { Agonist of PXR } \\
\text { Antagonist of ThR }\end{array}$ & $\begin{array}{l}\text { Kuiper et al. (1998), Morito } \\
\text { et al. (2001), Moriyama } \\
\text { et al. (2002), Lee et al. } \\
\text { (2003), Takayanagi et al. } \\
\text { (2006), Matsushima et al. } \\
\text { (2007) and Sui et al. (2012) }\end{array}$ \\
\hline $\begin{array}{l}\text { Genistein } \\
\quad \text { (phytoestrogen) }\end{array}$ & $\begin{array}{l}\mathrm{RBA} E \mathrm{ER} \beta \gg \mathrm{ER} \alpha \\
\text { Activates } \\
\text { transcription via ERE }\end{array}$ & $\begin{array}{l}\text { Anti-androgen via ER } \beta \\
\text { action Very weak } \\
\text { binding to AR } \\
(0.003 \text { RBA DHT) }\end{array}$ & & $\begin{array}{l}\text { Kuiper et al. (1998), Morito } \\
\text { et al. (2001), Bektic et al. } \\
\text { (2004) and Freyberger \& } \\
\text { Ahr (2004) }\end{array}$ \\
\hline $\begin{array}{l}\text { Coumestrol } \\
\text { (phytoestrogen) }\end{array}$ & $\begin{array}{l}\mathrm{RBA} E \mathrm{ER} \beta \gg \mathrm{ER} \alpha \\
\text { Activates } \\
\text { transcription via ERE }\end{array}$ & No IC50 demonstrated & & $\begin{array}{l}\text { Kuiper et al. (1998) and } \\
\text { Freyberger \& Ahr (2004) }\end{array}$ \\
\hline DDT and metabolites & $\begin{array}{l}\text { Binds } E R \alpha \text { and } E R \beta, \\
\text { transcriptional } \\
\text { activation }\end{array}$ & Anti-androgen ( $\left.p, p^{\prime}-D D E\right)$ & & $\begin{array}{l}\text { Kelce et al. (1995), Klotz et al. } \\
\text { (1996) and Kuiper et al. } \\
\text { (1998) }\end{array}$ \\
\hline Dioxins & $\begin{array}{l}\text { TCDD modulates ER } \alpha \\
\text { activity through } \\
\text { binding AhR }\end{array}$ & $\begin{array}{l}\text { TCDD blocks androgen- } \\
\text { dependent proliferation } \\
\text { of LNCaP cells }\end{array}$ & $\begin{array}{l}\text { Crosstalk with COUPTF1 } \\
\text { and ERR } \alpha \text { via AhR }\end{array}$ & $\begin{array}{l}\text { Klinge et al. (2000), } \\
\text { Ohtake et al. (2003) and } \\
\text { Barnes-Ellerbe et al. (2004) }\end{array}$ \\
\hline $\begin{array}{l}\text { Polychlorinated } \\
\text { biphenyls }\end{array}$ & Weak binding & Weak binding & & $\begin{array}{l}\text { Kuiper et al. (1998) and Fang } \\
\text { et al. (2003) }\end{array}$ \\
\hline
\end{tabular}

RBA, relative binding affinity; ER, oestrogen receptor; $A R$, androgen receptor; DES, diethylstilbestrol; ERR, oestrogen-related receptor; BPA, bisphenol A; PXR, pregnane X receptor; ThR, thyroid hormone receptor; TCDD, 2,3,7,8-tetrachlorodibenzo-p-dioxin; AhR, aryl hydrocarbon receptor.

http://erc.endocrinology-journals.org DOI: $10.1530 /$ ERC-13-0342
(C) 2014 Society for Endocrinology Printed in Great Britain 


\section{ER signalling}

The most abundant endogenous oestrogens in normal premenopausal women, oestrone $\left(\mathrm{E}_{1}\right)$ and oestradiol $\left(\mathrm{E}_{2}\right)$ (Fig. 1), are lipophilic steroid hormones that activate cognate receptors in target tissues to alter cell function (Gruber et al. 2002). In women, there are two subtypes of ER encoded by separate genes, ER $\alpha$ and ER $\beta$, both of which are widely expressed in cells throughout the reproductive system (reviewed in Gibson \& Saunders (2012)). Splice variant isoforms of both the ER $\alpha$ (ESR1) and ER $\beta$ (ESR2) genes have been described and their ability to participate in oestrogen-dependent signalling investigated using cellbased systems (Moore et al. 1998, Gibson \& Saunders 2012). A number of SNPs associated with the same genes have also been documented, some of which are associated with the risk of developing endometrial cancer (Ashton et al. 2009).

Ligand-bound ERs can influence gene expression via several different pathways (reviewed in Hall et al. (2001), Nilsson et al. (2001) and Matthews \& Gustafsson (2003)). Briefly, ligand binding to $\mathrm{ER} \alpha$ and $\mathrm{ER} \beta$ causes a
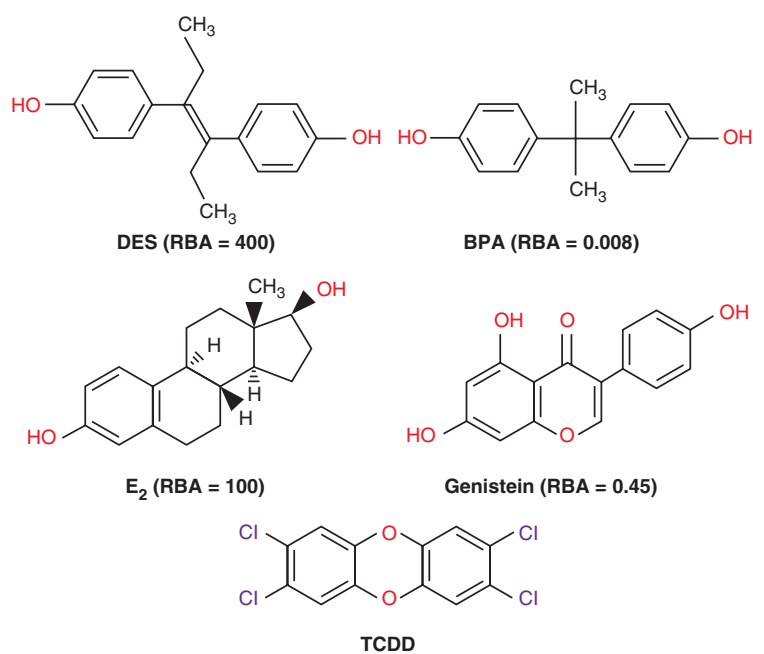

Figure 1

Two-dimensional (2D) chemical structure of ligands diethylstilbestrol (DES), oestradiol $\left(E_{2}\right)$, genistein, bisphenol A (BPA) and their relative binding affinity (RBA) for oestrogen receptor $\alpha(E R \alpha)$ and the 2D chemical structure of the aryl hydrocarbon receptor (AhR) ligand 2,3,7,8-tetrachlorodibenzop-dioxin (TCDD). DES, $E_{2}$ and genistein contain key structural features critical to ER binding such as phenolic ring and $17 \beta-O H$ group. DES has the greatest affinity for $E R \alpha(R B A=400)$ due to the presence of ethyl groups, which increase the hydrophobicity of DES and increase interaction with the $\mathrm{ER} \alpha$ binding pocket site. BPA has a phenolic ring but lacks a $17 \beta-\mathrm{OH}$ group and only binds $E R \alpha$ weakly (RBA $=0.008$ of $E_{2}$ ). TCDD lacks the characteristic structural features of an ER ligand and does not bind directly to ERs. RBA and structural analysis based on observations reported in structure-activity relationship study by Fang et al. (2001). Chemical structures obtained from http://www.chemspider.com/(accessed Sept. 2013). conformational change in the shape of the protein that is different for agonists and antagonists (Paige et al. 1999). An understanding of the 3D structure of both ER $\alpha$ and ER $\beta$ has allowed chemists to develop receptor-selective agonists and antagonists (Sun et al. 1999, Paruthiyil et al. 2009). Furthermore, modelling of putative ligandreceptor interactions is now used for in silico screening allowing investigators to predict whether compounds are likely to interact with ERs (Biesiada et al. 2011) and has been applied to environmental pollutants (Li et al. 2012a). Following ligand binding, ERs will form homo- or heterodimers, depending on whether one or both receptors are present within the cell; dimers interact with other co-regulatory proteins at binding sites in the promoter regions of genes either directly or in association with other transcription factors such as Jun/Fos and Sp1 (reviewed in Nilsson et al. (2001) and Heldring et al. (2007)). In summary, prediction of the effects of an oestrogenic ligand, be it natural, synthetic, or an EDC, on cell function needs to consider whether it can bind to one or both ERs, and whether it can out-compete other ligands present within the tissue microenvironment, as well as the nature of the binding sites within the regulatory elements of the target genes.

\section{ER expression and actions of oestrogens in reproductive tract tissues}

During the first trimester of pregnancy (9.5-11.5 weeks of gestation), the female reproductive tract develops from Müllerian ducts of mesodermal origin. The vagina, cervix and uterus develop into distinct organs as a result of differentiation of the epithelium mediated by the underlying mesenchyme of each organ (Cunha 1976) and the activities of the distal Hox gene cluster (reviewed in Daftary \& Taylor (2006)). The fetal ovary has only a limited capacity for sex steroid biosynthesis (Fowler et al. 2011), but from puberty to menopause, a woman's reproductive system is exposed to successive waves of oestrogen and progesterone secreted by the ovaries (Abraham 1974, Johannisson et al. 1987). Uterine endometrial gland formation starts in utero but is only completed at puberty when sex steroid levels rise. Steroids are also required for differentiation of the cervix (Hwang et al. 2009) that is completed during puberty when basal columnar epithelial cells transform into squamous epithelium.

$\mathrm{ER} \alpha$ and $\mathrm{ER} \beta$ are expressed in cells distributed throughout the female reproductive tract. In the adult human endometrium, their expression is both temporally and spatially regulated (Critchley et al. 2001). For example, 
expression of ER $\alpha$ varies in a cycle-dependent manner within the functional layer; ER $\alpha$ is down-regulated in both epithelial and stromal cells during the secretory phase whereas expression is maintained in the same cell types within the basal layer (Critchley et al. 2001). Expression of ER $\beta$ exhibits little dynamic change across the cycle (Critchley et al. 2001). A truncated variant (ERß2) that can form heterodimers with full-length ERs but does not contain a functional ligand binding pocket is also expressed (Critchley et al. 2002, Sierens et al. 2004) as are orphan receptors implicated in regulation of oestrogen responsiveness (Bombail et al. 2008, 2010). Notably, endothelial and immune cells within the human endometrium are immunopositive for ER $\beta$ but do not contain ER $\alpha$ protein (Henderson et al. 2003, Greaves et al. 2013). In the human fallopian tube, ER mRNAs are constitutively expressed during the menstrual cycle and have been immunolocalised to epithelial, stromal and smooth muscle cells (Horne et al. 2009). In the cervix, expression of $\mathrm{ER} \alpha$ and $\mathrm{ER} \beta$ has been documented in both stromal and epithelial cells (Taylor \& Al-Azzawi 2000), whereas endothelial cells and leukocytes appear to express ER $\beta$ alone as is the case in the endometrium (Stygar et al. 2001). Both receptor subtypes are expressed in the myometrium with evidence for altered ratios between ER $\alpha$ and ER $\beta$ in tissue recovered from pre- and postmenopausal women
(Sakaguchi et al. 2003), a reported increase in ER $\beta$ in myometrium at the end of pregnancy ( $\mathrm{Wu}$ et al. 2000) and evidence that myometrial endothelial cells are ER $\beta$-positive/ER $\alpha$-negative (Greaves et al. 2013).

Studies using cells, tissue explants and animal models have highlighted the importance of ER $\alpha$-dependent signalling in $\mathrm{E}_{2}$-dependent cell proliferation and expression of progesterone receptors (Harris et al. 2002, Punyadeera et al. 2004). In ovariectomised (ovx) mice, injection of $\mathrm{E}_{2}$ is sufficient to stimulate a three- to fourfold increase in uterine wet weight (Lubahn et al. 1993), a finding that is the basis of the widely used uterotrophic assay (Table 2). Female ER $\alpha$ knockout (ER $\alpha \mathrm{KO}$ ) mice have hypoplastic uteri with sparse glands (Lubahn et al. 1993). Although the uterine weight in ER $\beta K O$ mice is normal, they are hyper-responsive to $\mathrm{E}_{2}$-stimulated uterine proliferation (Dupont et al. 2000), a finding consistent with studies using cell lines that have demonstrated co-expression of ER $\beta$ with ER $\alpha$ can restrain the activities of the latter (Hall \& McDonnell 1999). A study exploring the effects of oestrogens on endothelial cells derived from the endometrium and myometrium has recently reported that signalling via ER $\beta$ has opposite effects on network formation in the two cell types (Greaves et al. 2013). Thus, oestrogen action is dependent on ER isoform expression, which is cell-context-dependent.

Table 2 Models for assessing oestrogenicity and the responses of selected EDC

Oestrogenic assay

Uterotrophic assay

Luciferase reporter assay (ERE)

Luciferase reporter assay (AP1)

Yeast $\beta$-galactosidase reporter assay

Transcription of oestrogenresponsive genes

\section{EDC}

DES; agonist

BPA; mixed agonist/antagonist concentration dependent

Phytoestrogens: genistein, coumestrol; mixed agonist/antagonist concentration dependent

PCBs; agonist

TCDD; antioestrogen

Strong affinity: DES (ER $\alpha$ and $E R \beta)$, coumestrol (ER $\beta^{1}$ )

Moderate affinity: genistein ${ }^{1}$

Weak affinity: DDT metabolites, PCBs, BPA ${ }^{1,2}$

Transcriptional activation: DES, BPA, In vitro, both ER isoforms genistein, coumestrol, PCBs, DDT investigated

Transcriptional activation: BPA, DDT

Transcriptional activation: DES, coumestrol, BPA, DDT metabolites

DES, BPA, genistein, coumestrol, benzophenones, PBDE

\section{Comments}

In vivo, ER $\alpha$-mediated. Model organisms; mice, rat. Immature animals (prepubertal) or ovariectomy of adult animals

Primary endpoint; wet or dry uterine weight

${ }^{1}$ RBA for both ER isoforms assessed

${ }^{2}$ RBA for total rat uterine cytosol ER

In vitro, both ER isoforms investigated

In vitro. Transient expression of human receptors

E.g. PGR, CXCL12

\section{References}

Faqi \& Chahoud (1998), Arcaro et al. (1999), Markey et al. (2001), Jefferson et al. (2002), Kim et al. (2002) and Ohta et al. (2012)

${ }^{1}$ Kuiper et al. (1998)

${ }^{2}$ Blair et al. (2000)

Kuiper et al. (1998), Frigo et al. (2002) and Li et al. (2013)

Frigo et al. (2002) and Li et al. (2013)

Gaido et al. (1997)

Ceccatelli et al. (2006), Newbold et al. (2007) Kerdivel et al. (2013) and Li et al. (2013) 


\section{Oestrogen biosynthesis and ER expression in benign and malignant endometrial tract disorders}

Altered expression of enzymes involved in steroid biosynthesis resulting in an increased capacity to produce oestrogens has been reported for both benign and malignant disorders of the reproductive system. Uterine fibroids (leiomyomas) are benign tumours that arise as a result of aberrant proliferation of smooth muscle cells within the myometrium (Cramer \& Patel 1990). Tissue concentrations of oestrogens are elevated in fibroids (Pasqualini et al. 1990) and oestrogens are thought to drive cell proliferation.

In the European Prospective Investigation into Cancer and Nutrition (EPIC) study, the presence of endometrial cancer was positively associated with increased circulating levels of testosterone, $\mathrm{E}_{1}$ and $\mathrm{E}_{2}$ (Allen et al. 2008). An increase in expression of the CYP19A1 gene encoding the aromatase protein, which plays a critical regulatory role in biosynthesis of $\mathrm{E}_{1}$ and $\mathrm{E}_{2}$, has been documented in both endometrial and cervical cancers, consistent with a role for local $\mathrm{E}_{2}$ biosynthesis in disease progression (Bulun et al. 1994, Nair et al. 2005).

Expression of ERs has been documented in uterine smooth muscle (leiomyosarcomas) (Rodriguez et al. 2011), endometrial (Collins et al. 2009) and cervical (Nair et al. 2005) cancers. Studies examining expression of ERs in stage 1 endometrial adenocarcinomas have highlighted a reduction in expression of $\mathrm{ER} \alpha$ and progesterone receptor in tissues graded as poorly differentiated and an inverse relationship between ER $\alpha$ and the COX-2 enzyme (Collins et al. 2009) consistent with a role for oestrogens in regulating expression of inflammatory mediators that can influence tumour progression (Wallace et al. 2010). In contrast to cells within the normal endometrium, proliferation of epithelial cells within endometrial adenocarcinomas does not appear to be ER $\alpha$ dependent, which may in part explain the mixed results obtained using aromatase inhibitors to treat endometrial cancer (Bulun et al. 2007).

\section{Evidence that oestrogens increase the risk of developing a reproductive cancer}

Oestrogens can act as potent mitogens in ER-positive cells with continual exposure to an oestrogenic stimulus having the potential to promote DNA instability, cellular hyperplasia and neoplastic transformation of epithelial cells into carcinomas (Key \& Pike 1988). In normal menstrual cycles, the effects of oestrogen-driven proliferation on endometrial tissue are limited by progesterone produced by the corpus luteum following ovulation, with progesterone down-regulating expression of ER $\alpha$ during the secretory phase (Critchley et al. 2001). Established risks of developing endometrial cancer such as high BMI (Arem et al. 2013), nulliparity, early onset of menses (Purdie \& Green 2001) and the duration of the menopausal transition (Hale et al. 2002) are associated with increased lifetime exposure to oestrogens.

An increased risk of developing endometrial cancer is associated with exposure to tamoxifen, a selective ER modulator that exhibits mixed antagonist/agonist activity (Jordan 2003). Although tamoxifen is effective as a treatment for breast cancer by virtue of its antagonism of ERs expressed in breast cancer cells, in uterotrophic assays, it behaves as an agonist stimulating uterine weight, epithelial height, and the transcription of ER-responsive genes (Kwekel et al. 2009). The uterotrophic effects of tamoxifen are consistent with an increased risk of endometrial cancer observed in patients who have received tamoxifen treatment for breast cancer (Kedar et al. 1994, Bergman et al. 2000).

Postmenopausal oestrogen-only hormone replacement therapy has been associated with increased occurrence of endometrial, ovarian and breast cancers (Lacey et al. 2002, Beral et al. 2005b); however, inclusion of progestagens in the hormone replacement therapy (HRT) formulations is reported to reduce risk (Beral et al. 2005a), consistent with the physiological effect of progesterone in counteracting oestrogen-driven proliferation. Furthermore, the use of the combined oral contraceptive pill is apparently protective against endometrial cancer risk (Emons et al. 2000), an effect that persists even after discontinuation of use (La Vecchia et al. 1996). Thus, exposure to oestrogens unopposed by progestagens poses greater risk of endometrial cancer.

Clinically, endometrial cancers have classically been divided into oestrogen-dependent type I and the less common, but clinically more aggressive, oestrogenindependent type II. In women, the majority of endometrial cancers are oestrogen-dependent type I cancers with increased risk associated with exposure to excess oestrogens (Emons et al. 2000). However, in a recent examination of the risk factors for type I and type II endometrial cancer from 14069 endometrial cancer cases, Setiawan et al. (2013) reported that type I and type II endometrial cancer share many common aetiological factors. Notably, parity, oral contraceptive use, cigarette smoking, age at menarche and diabetes were found to be http://erc.endocrinology-journals.org DOI: 10.1530/ERC-13-0342
(C) 2014 Society for Endocrinology Printed in Great Britain 
associated with both tumour types to a similar extent. However, BMI had a greater effect on risk of type I tumours than type II. Thus, while increased lifetime exposure to oestrogens is likely to have the greatest effect on the risk of developing type I endometrial cancers, there may also be some interaction with risk of developing type II endometrial cancers. To date, the majority of animal models assessing the effects of EDC on reproductive tract cancers have assessed development of oestrogen-dependent adenocarcinomas, i.e. modelling type I endometrial cancers. As such the investigation into the influence of EDC on endocrine-related gynaecological cancers has been largely restricted to this specific subset of reproductive tract cancers.

Persistent infection with human papillomavirus (HPV) is the predominant risk factor for invasive cervical carcinoma and precursor lesions (Bosch \& de Sanjose 2007). Oestrogens are thought to modify HPV-associated risk. For example, in HPV16 transgenic mice (the HPV transgenic mouse model), oestrogen is required for the genesis and persistence of cervical cancer (Brake \& Lambert 2005). In addition, studies in transgenic mice in which stromal ER $\alpha$ has been deleted have confirmed an essential requirement for ER $\alpha$ expression in oestrogendependent cervical cancer in the HPV mouse model (Chung et al. 2013). Interestingly, results from the EPIC study found that an increased risk of developing cervical cancer in premenopausal women was associated with increased concentrations of free testosterone and circulating levels of $\mathrm{E}_{2}$ (Rinaldi et al. 2011).

\section{Endocrine disruptors implicated in reproductive tract disorders and cancer}

As the female reproductive tract is exquisitely sensitive to changes in bioavailable oestrogens, exposure to substances that mimic the action of oestrogens or disrupt normal oestrogen homoeostasis is likely to pose an increased risk to developing cancers of the reproductive tract. Due to the ubiquitous nature of EDC exposure and the pleiotropic action(s) of EDC, assessing the link between lifetime exposure and the associated risk of reproductive cancer for any single EDC or pathology is difficult and epidemiological evidence is often contradictory. Important evidence that EDC can alter oestrogen-dependent signalling pathways and thereby contribute to cancer risk has come from studies using in vitro and animal model systems that are outlined below; less attention has been paid to the influence of EDC on morbidity and mortality of cancer sufferers.

\section{Models for assessing oestrogenicity of EDC}

A summary of the assays that are most widely quoted in studies analysing the oestrogenicity of EDC is provided in Table 2. Primary methods for identifying oestrogenic effects of EDCs typically involve uterotrophic assays in laboratory animals such as mice or rats. This assay is based on the classical physiological response of the uterus following exposure to oestrogen: increased uterine weight due to fluid imbibition and increased epithelial proliferation. In this assay, EDC are considered oestrogenic if they induce increases in uterine dry or wet weight or affect other endpoints such as epithelial proliferation, epithelial cell height or the expression of oestrogen-responsive genes. Uterotrophic assays are reported to give variable responses depending on the specifics of the assay protocol such as dosing regimen, route of administration and whether immature or mature ovx animals are used (Kang et al. 2000). A limitation of this assay is that the uterotrophic response is mediated via $\mathrm{ER} \alpha$ and therefore only EDC that are able to bind, activate or modulate ER $\alpha$ will elicit a positive response. To address this limitation, cell-based assays have been developed to investigate the capacity for EDC to promote ER-dependent transcription (Shelby et al. 1996), providing the opportunity for assessment of activity on ER $\beta$ or combinations of ER $\alpha / \operatorname{ER} \beta$ as well as other receptors (Table 2) that must be born in mind when assessing the risks associated with exposure/bioaccumulation.

\section{Oestrogenic EDC}

EDC from a variety of sources have been identified as having oestrogenic activity. These include industrial products and pollutants, plastic components, detergents, pesticides, a number of household cleaning products as well as personal care products such as sunscreens, cosmetics and hair dyes (reviewed in De Coster \& van Larebeke (2012)). The oestrogenic activities of EDC such as diethylstilbestrol (DES) and BPA have been comprehensively studied and are described in the following sections. However, it is notable that several other EDC are recognised as having oestrogenic properties but their effect, particularly on the development of reproductive tract cancers, has not been extensively assessed. For example, polybrominated diphenyl ethers (PBDE) are flame-retardant additives found in several consumer products. PBDE is reported to alter the expression of oestrogen target genes in the rat uterus (Ceccatelli et al. 2006) and is reported to induce DNA damage in human 
neuroblastoma cells (Pellacani et al. 2012). Alkylphenols such as 4-n-octylphenol, 4-tert-octylphenol and nonylphenol have weak oestrogenic activities (Kuiper et al. 1998). At high doses $(50 \mathrm{mg} / \mathrm{kg})$, microarray analysis has revealed that nonylphenol activates similar genes to $E_{2}$ in the mouse uterus (Watanabe et al. 2004). Nonylphenol may also influence endometrial cancer development through activation of pregnane $\mathrm{X}$ receptor, which is highly expressed in human endometrial cancers (Masuyama et al. 2003, 2007). Chemicals that absorb u.v. (u.v. filters) are widely used in sunscreens and in a variety of cosmetic products for protection against u.v. radiation. Using a recombinant yeast reporter assay, Kunz \& Fent $(2006 b)$ investigated hormonal activities of u.v. filters and reported that several of the compounds assessed exhibited agonist effects at ER $\alpha$ : benzophenone-1 (BP1), benzopehnone-2 (BP2), 4-hydroxybenzophenone (4HB), 4,4'-dihydroxybenzophenone (4DHB) and ethyl-4 amino benzoate (et-PABA); furthermore, several of the u.v. filters exhibited androgenic, anti-androgenic and anti-oestrogenic activity highlighting a diverse capacity for endocrine disruption. Notably, BP1, 4HB, 4DHB and et-PABA exhibited both oestrogenic and anti-androgenic activities (Kunz \& Fent $2006 b$ ). In a further study, the capacity for mixtures of u.v. filters to activate ER $\alpha$-mediated transcription was investigated in a recombinant yeast assay and it was found that low concentration mixtures of u.v. filters exhibited a synergistic increase in activity of an ER $\alpha$-driven reporter gene (Kunz \& Fent 2006a). In addition, BP2 is reported to increase uterine wet weight and induce expression of oestrogen target genes in the rat uterus (Schlecht et al. 2006). BPs are reported to increase proliferation of MCF-7 cells in an ER-dependent manner, stimulate reporter gene activity via oestrogen response elements (ERE) and Sp1 but not AP1 and increase mRNA expression of ER target genes such as CXCL12, amphiregulin, pS2 and progesterone receptor (Kerdivel et al. 2013).

\section{Diethylstilbestrol}

DES, a synthetic non-steroidal oestrogen, is often regarded as the archetypal endocrine disruptor (Fig. 1). From about 1940 to 1970 , DES was given to pregnant women in the mistaken belief that it would reduce the risk of pregnancy complications. Herbst et al. (1971) reported a probable link between DES and vaginal clear cell adenocarcinoma in girls and young women who had been exposed to this drug. It is estimated that five to ten million people were exposed to DES, including the pregnant mothers who received treatment and their offspring. Of the several million women exposed to DES in utero, a cohort of 4653 DES-exposed women have been followed up to investigate the long-term consequences of exposure (Hoover et al. 2011). Patient data stratified to account for the extent of exposure or dose effects of DES identified an association between treatment of mothers earlier during their pregnancy and adverse vaginal epithelial changes at a younger age in their offspring (Hoover et al. 2011). While DES exposure is associated with increased risk of breast and cervical/vaginal clear cell adenocarcinoma, several studies have indicated that there is no associated risk of endometrial or ovarian cancer (Troisi et al. 2007, Hoover et al. 2011). As endometrial cancer is most likely to present after menopause, many of the DES-exposed women may not yet be old enough to determine whether they are at excess risk, as in the 2011 report only $27 \%$ were older than 50 years (Hoover et al. 2011). Although to date epidemiological data indicate that DES-exposed women may not be at increased risk of developing endometrial cancer, studies in animal models provide evidence to the contrary.

In the early 1990s, Newbold et al. (1990) developed a mouse model for investigating hormonal carcinogenesis in mice by investigating the effects of neonatal exposure to oestrogens on cancer development. Treatment of CD1 neonatal mice with DES on postnatal days $1-5$, which correspond to late prenatal human development, resulted in $90 \%$ of DES-exposed mice developing uterine adenocarcinomas after 18 months while none of the control animals had neoplastic lesions (Newbold et al. 1990). Crucially, while administration of DES increased the risk of uterine adenocarcinoma, endogenous oestrogen was required for tumour development with prepubertal ovariectomy preventing tumour development (Newbold et al. 1990). In DES-exposed women, vaginal and cervical carcinomas were only detected post-menarche consistent with a requirement for endogenous oestrogen in tumour development (Hoover et al. 2011). ER $\alpha$ knockout mice (ERKO) did not develop tumours following neonatal DES exposure (Couse \& Korach 2004); transgenic mice overexpressing ER $\alpha$ displayed accelerated tumour development (Couse et al. 1997) but mice with a dominant negative isoform of ER $\alpha(\mathrm{ER} \Delta 3)$ were not protected (Davis et al. 2012), highlighting the complexity of the molecular signalling mechanisms involved.

Interestingly, gene expression analysis indicates that developmental DES exposure results in persistent altered gene expression of oestrogen-responsive genes in the uterus that may explain the increased susceptibility to tumour development. Gene ontology analysis of microarray data revealed altered expression of genes involved in 
cell growth, differentiation and adhesion (Newbold et al. 2007). Kabbarah et al. (2006) collected uterine cancer tissue RNA from DES-exposed mice by laser capture microdissection to minimise contamination with other cell types and performed targeted transcriptional profiling. Interestingly, the tumour suppressor PTEN was down-regulated in the majority of tumours, analogous to loss of PTEN expression in human tumours (Mutter et al. 2000). In addition, genes associated with cell adhesion, such as Decorin, were down-regulated in DES-induced tumours while suppressor of cytokine signalling 3 (Socs3) was over-expressed (Kabbarah et al. 2006). Other studies have also identified molecular similarities between DESinduced tumours in mice (Kabbarah et al. 2003) and endometrial cancer in humans, such as microsatellite instability brought about by defects in expression of DNA mismatch repair genes such as MSH2 (Cederquist et al. 2004) and MSH6 (Goodfellow et al. 2003).

It could be argued that the apparent trans-generational effect of endocrine disruption is of greater significance. Following neonatal DES exposure in mice, the F1 generation of DES daughters have an increased incidence of uterine adenocarcinoma. Newbold et al. (1998) found that $31 \%$ of $\mathrm{F} 1$ females from the maternal germ cell lineage developed tumours after 18 months despite there being no exogenous endocrine exposure in these animals, highlighting the potential for future risk to the daughters of DES-exposed women. DES is reported to induce epigenetic changes. Altered methylation patterns have been reported for several uterine genes that are permanently dysregulated after developmental DES exposure; lactoferrin and c-Fos are permanently up-regulated following neonatal DES exposure to due to hypomethylation of the promoter region (Li et al. 1997, 2003).

DES has been reported to promote hypermethylation of the homeobox gene Hoxa10 in mice exposed in utero to DES. DES exposure was also associated with increased expression of DNA methyltransferases 1 and $3 \mathrm{~b}$ leading to long-term altered expression of Hoxa10 (Bromer et al. 2009). Contrary to the reported action of DES on Hoxa10, exposure to BPA in mice in utero results in hypomethylation of the Hoxa10 promoter, which leads to enhanced binding of ER $\alpha$ to EREs in the promoter region and an increase in an ERE-driven reporter gene in vitro (Bromer et al. 2010).

Thus, epigenetic changes in uterine genes may indicate a possible mechanism for trans-generational effects of DES because altered expression of genes is reported to persist in DES-lineage females.

\section{Bisphenol A}

BPA is an industrial chemical primarily used to make plastics and is also found in epoxy resins that line many canned foods and beverages (Brotons et al. 1995). BPA was identified as an oestrogenic substance by Krishnan et al. (1993) who reported that it had weak binding affinity for ER (1/2000th that of $\left.E_{2}\right)$, was able to induce proliferation of MCF7 cells (ER $\alpha$-positive, breast epithelial carcinoma cell line) and expression of progesterone receptor. BPA has structural similarities to $\mathrm{E}_{2}$ (Fig. 1) and has been shown to interact with both $\mathrm{ER} \alpha$ and $\mathrm{ER} \beta$ (Kwekel et al. 2009). In vitro assays have confirmed that BPA can activate EREs in a luciferase reporter assay (Table 2). The activity of BPA has also been investigated using the ER action indicator (ERIN) mouse, which has been engineered to express a transgene with an oestrogen-responsive promoter linked to a $\beta$-galactosidase reporter gene (Nagel et al. 2001). Interestingly, BPA was reported to be a potent agonist of ER transcriptional activity in the uterus of the ERIN mouse (Nagel et al. 2001) but other studies report that BPA only weakly stimulated uterine weight gain in mice (Papaconstantinou et al. 2000, Tinwell et al. 2000) and rats (Ashby \& Tinwell 1998, Yamasaki et al. 2000). BPA also weakly activated the IGF signalling pathway via ER $\alpha$ in the uterus of ovx adult mice, leading to an increase in mitotic cells, indicating that BPA may also promote epithelial proliferation via alternative signalling pathways (Klotz et al. 2000). In a series of in vitro assays, Li et al. $(2012 b, 2013)$ demonstrated that BPA and the fluorinated derivative bisphenol AF (BPAF) may activate both ER $\alpha$ and ER $\beta$ but that activation was both cell-type- and concentrationdependent. For example, in Ishikawa cells (endometrial adenocarcinoma cell line), BPA at concentrations lower than $10 \mathrm{nM}$ antagonised $\mathrm{E}_{2}$-mediated $\mathrm{ER} \alpha$ activation of luciferase activity while in HeLa cells (cervical adenocarcinoma cell line) similar concentrations of BPAF antagonised $\mathrm{E}_{2}$-mediated ER $\beta$ activation of luciferase activity (Li et al. 2012b). BPA and BPAF at concentrations greater than $10 \mathrm{nM}$ and up to $100 \mathrm{nM}$ were reported to act as agonists through both ER $\alpha$ and ER $\beta$ (Li et al. 2012b, 2013).

In a recent study investigating the effect of BPA on human endometrial stromal cell (ESC) differentiation, BPA was found to decrease proliferation of ESC and decrease expression of mRNAs encoding CYP11A1, HSD17B1 and HSD17B2; however, this effect was only observed with high $(50-100 \mu \mathrm{M})$ doses (Aghajanova \& Giudice 2011). Serum concentrations of BPA measured in both pre- and postmenopausal women were significantly lower in patients with complex endometrial 
hyperplasia or endometrial cancer than in healthy controls (Hiroi et al. 2004).

BPA has been reported to alter expression/activity of enzymes involved in steroid synthesis and metabolism in the murine ovary (Peretz et al. 2011). Although the receptor involved in mediating this effect was not identified, it is notable that BPA can also bind with high affinity to the orphan receptor oestrogen-related receptor $\gamma$ (Takayanagi et al. 2006) and may also bind androgen receptors (Lee et al. 2003) both of which are expressed in the ovary. While BPA has been shown to affect murine ovarian function, an analysis of human urinary BPA levels found no significant association with expression of CYP19 in human granulosa cells (Ehrlich et al. 2013) leaving the question of whether effects of BPA in women could be mediated by alterations in ovarian function unanswered.

\section{Dichlorodiphenyltrichloroethane}

Dichlorodiphenyltrichloroethane (DDT) and its metabolites bind ERs and have oestrogenic activity (Klotz et al. 1996). Interestingly, DDT has been shown to mediate ER-dependent changes in gene expression by binding either ERE or AP-1 binding sites in promoters. In addition, DDT has been shown to activate ER-independent transcription in Ishikawa cells (Frigo et al. 2002). DDT and its metabolites have weak binding affinity for ER $\alpha$ and ER $\beta$, although o,p'-DDT has been reported to activate ER $\alpha$ (Kuiper et al. 1998). Despite the reported oestrogenic activity of DDT, epidemiological evidence indicates that there is no significant association between organochlorine exposure and endometrial cancer risk (Sturgeon et al. 1998). In another study serum concentrations of chlorinated pesticides were measured in 154 endometrial cancer patients and 205 healthy controls. While the study found that concentrations of $\mathrm{p}, \mathrm{p}^{\prime}$-DDT, $\mathrm{p}, \mathrm{p}^{\prime}$-dichlorodiphenyldichloroethylene ( $\mathrm{p}, \mathrm{p}^{\prime}$-DDE), $\beta-\mathrm{HCH}$ and oxychlordane were significantly increased in endometrial cancer patients, when concentrations were adjusted for age and BMI, no significant increased risk was found (Weiderpass et al. 2000).

\section{Dioxins}

Polychlorinated dioxins, furans and polychlorinated benzene are a group of industrial chemicals that are persistent toxic environmental pollutants. Tetrachlorodibenzo-p-dioxin (TCDD) is a designated carcinogen and the most potent dioxin (Fig. 1). Human exposure is prevalent, largely through diet; dioxins are slowly metabolised and due to their lipophilic nature tend to bioaccumulate (Kogevinas 2001). Dioxins target the endocrine system and have been reported to alter metabolism of oestrogens and androgens (Cooke et al. 1998, van Duursen et al. 2003).

The potential risk of dioxins to human health has been evident from series of industrial exposures, the most informative of which involved accidental exposure of industrial workers to dioxins in Seveso in 1976. Epidemiological studies have revealed an increased overall risk for all cancers and increased risk of breast and endometrial cancer from dioxin exposure in adults (Kogevinas et al. 1997, Bertazzi et al. 1999, Kogevinas 2001).

Dioxins mediate cellular effects through binding of the aryl hydrocarbon receptor (AhR), which heterodimerises with AhR nuclear translocator (ARNT) to mediate transcription through xenobiotic response elements in promoter regions of target genes (Mimura \& Fujii-Kuriyama 2003). TCDD can mediate cell-specific oestrogenic and antioestrogenic effects (Grochowalski et al. 2001) and the action of TCDD seems to involve crosstalk between AhR and ER (Gierthy et al. 1996). In Ishikawa cells derived from an endometrial adenocarcinoma expressing ER $\alpha$ and AhR, TCDD treatment reduced $\mathrm{E}_{2}$-mediated increases in cell proliferation and ER-mediated transcription (Wormke et al. 2000). Although this study indicates that stimulation of AhR by dioxins may be protective against oestrogenic stimulation and development of endometrial cancers, Ohtake et al. (2003) suggested that oestrogen signalling could be modulated through association of unliganded ER with AhR. Specifically, following activation of AhR and heterodimerisation with ARNT, the receptor complex is able to recruit unliganded ER and the co-activator p-300 to oestrogen-responsive gene promoters resulting in transcriptional activation (Ohtake et al. 2003), an affect that was attenuated by ligand-bound ER. Thus, low-level exposure to dioxins may only mediate stimulatory effects in the absence/low bioavailability of $\mathrm{E}_{2}$, indicating that premenarche and postmenopause the reproductive tract might be more vulnerable to adverse stimulation by dioxins.

\section{Phytoestrogens}

Phytoestrogens are non-steroidal compounds present in dietary foodstuffs and include isoflavones such as genistein, daidzein and coumestrol (Fig. 1). Phytoestrogens are found in a range of legumes and soya-based products, and individuals with diets that are predominantly based on consumption of these foodstuffs have been the focus of several epidemiological studies. It has been reported that http://erc.endocrinology-journals.org DOI: 10.1530/ERC-13-0342
(C) 2014 Society for Endocrinology Printed in Great Britain 
higher exposure to isoflavones in postmenopausal women was associated with lower plasma $\mathrm{E}_{2}$ (Horn-Ross et al. 2003). However, in a randomised, double-blind, placebocontrolled study of 376 healthy postmenopausal women, the individuals who received $150 \mathrm{mg}$ isoflavones per day showed a significant increase in simple endometrial hyperplasia when compared with women given a placebo for 5 years (Unfer et al. 2004). In a recent prospective study conducted on 70000 low-risk individuals, vegan diets were found to offer statistically significant protection from female-specific cancers, although the authors commented that this may reflect, in part, effects on BMI (TantamangoBartley et al. 2013).

Standard oestrogen response assays have revealed that phytoestrogens can induce increased uterine wet weight, bind ER and induce ER-dependent transcription (Jefferson et al. 2002). In mature ovx female rats, 3 days of oral administration of genistein produced a dose-dependent increase in uterine wet weight and increased mRNA expression of complement component 3 (C3), an oestrogen-regulated gene (Diel et al. 2001). Interestingly, in the same study, the authors also examined the uterine and vaginal epithelia and observed dose-dependent increases in epithelial height (Diel et al. 2001). While genistein stimulated the uterus and vagina, in another assay using transplanted RUCA-1 endometrial adenocarcinoma cells in ovx rats, genistein did not affect tumour growth (Diel et al. 2001). Results from in vitro assays indicated that several phytoestrogens including genistein, daidzein and coumestrol can activate ER $\alpha$ - and ER $\beta$-dependent ERE luciferase activity (Li et al. 2013). Phytoestrogens may also promote activation of ER transcription via tethered mechanisms as cell-based assays have reported increased expression of luciferase reporter genes via AP-1 (but not Sp1) in HeLa cells expressing ER $\alpha$ (kaempferol, apigenin and coumestrol) or ER $\beta$ (daidzein) (Li et al. 2013).

Phytoestrogens have varying affinities for ERs and this affects their ability to promote ER-dependent ligandactivated transcription. In an elegant study by Kuiper et al. (1998), analysis of binding affinities of various phytoestrogens for $\mathrm{ER} \alpha$ and $\mathrm{ER} \beta$ revealed that several phytoestrogens, including coumestrol and genistein, have greater binding affinity for ER $\beta$ than ER $\alpha$. Interestingly, while most xenoestrogens have weak affinity for ERs, coumestrol and genistein have been reported to have a similar affinity to $\mathrm{E}_{2}$ for ER $\beta$ (Kuiper et al. 1998, Morito et al. 2001). It has also been reported that phytoestrogens promote distinct receptor confirmations when bound to ERs; 3D modelling based on X-ray crystallography of receptor structure has revealed that genistein binds to $\operatorname{ER} \beta$ and promotes a distinct confirmation of the AF-2 domain helix 12 in the ligand binding domain, resulting in an orientation that is more similar to that induced by ER antagonists (Pike et al. 1999). This distinct interaction with the ER ligand binding domain may in part explain the partial agonist characteristics of this ligand-receptor interaction. Thus, it is important to consider that individual phytoestrogens can have different effects on ERs, that their affinity for ER isoforms also differs, that the resultant transcriptional response may be variable and that their effects on the endometrium could vary during the menstrual cycle and be different depending on the grade of endometrial cancer.

\section{Evidence that expression of HOX genes can be altered by exposure to EDC}

It is apparent from a number of studies highlighted in this review and others (Crain et al. 2008) that EDCs can act as agonists of ERs to promote transcriptional activation of tissues in the reproductive tract. Results from epidemiological and animal studies are indicative of exposure during fetal and/or neonatal life (childhood) being particularly deleterious. A potential mechanism by which EDC may have lifelong effects on reproductive competence has been revealed by studies on members of the HOX gene cluster (HOX-A9, -A10, -A11 and -A13), which demonstrates that spatial and temporal expression of these genes is critical to formation and function of the female reproductive system (Taylor et al. 1997). Several studies have also provided robust evidence that expression of HOXA10 and A11 is steroid-regulated in the normal adult endometrium and that the products of these genes play a key role in preparation of the uterus for implantation (reviewed in Daftary \& Taylor (2006)). Alterations in Hox gene expression in the female reproductive tract have been reported in mice exposed to DES in utero (Block et al. 2000); mice with targeted deletion of ER $\alpha$ appear to be unaffected by DES treatment (Couse et al. 2001). EREs have been identified in the human HOXA10 promoter that were capable of binding both $\mathrm{ER} \alpha$ and $\mathrm{ER} \beta$ when tested in cellbased reporter systems (Akbas et al. 2004). Importantly, the authors of the study reported that $E_{2}$-induced activity at one of these EREs was approximately fivefold greater than DES-induced activity. This differential ERE activation was unrelated to ER or co-regulatory protein binding, indicating distinct transcription of $H O X A 10$ in response to different specific ligands. This may offer a plausible explanation for the molecular mechanism by which an EDC such as DES can drive altered HOX gene expression http://erc.endocrinology-journals.org DOI: $10.1530 / E R C-13-0342$
(C) 2014 Society for Endocrinology Printed in Great Britain 
resulting in malformations in the reproductive system (reviewed in Daftary \& Taylor (2006)). Results from studies using DES are also complemented by those on other EDC, indicating that the HOX gene-dependent signalling pathway may be vulnerable to modification by any agent that can alter ER activation. For example, in utero exposure to methoxychlor (Fei et al. 2005) or BPA (Smith \& Taylor 2007) can disrupt Hoxa10 gene expression in the uterus. Rats exposed to BPA during neonatal life are also reported to have impaired fertility characterised by reduced numbers of implantation sites (Varayoud et al. 2011).

\section{Evidence that early life exposure to EDC can alter onset of puberty or timing of menopause}

The proven association between lifetime oestrogen exposure and the risk of developing a gynaecological cancer means that onset of puberty and timing of menopause are both important risk factors. Precocious puberty, i.e. early menarche, has been reported to be associated with exposure to EDC (reviewed in Schoeters et al. (2008)), although the evidence is contradictory. Studies in women have reported an association of early puberty with exposure to DDT, DDE and polybrominated biphenyls (PBB) (Blanck et al. 2000, Vasiliu et al. 2004, Ouyang et al. 2005). However, women exposed to DES in utero do not differ in their age at menarche compared with unexposed women (Hoover et al. 2011) and other studies have reported that exposure to dioxins has no association with early puberty (Warner $e t a l$. 2004). A recent report from the Centers for Disease Control and Prevention's National Health and Nutrition Examination Survey (NHANES, 2003-2008) measured selected environmental chemicals and metabolites in urine in 440 young women (12-16 years of age). The authors reported an association between concentrations of 2,5-DCP, the major metabolite of dichlorobenzene, and earlier age of menarche (Buttke et al. 2012).

Early onset of menopause has been reported to increase the risk of endometrial cancer, particularly in obese women (Thomas et al. 2009), and DES-exposed women are reported to be at increased risk of early menopause (Hoover et al. 2011). Exposure to methoxychlor, a commonly used pesticide, advanced reproductive senescence in female rats (Gore et al. 2011), and exposure to the PCB mixture A1221 in utero resulted in elongated oestrous cycles, which is a characteristic of reproductive ageing (Walker et al. 2013). Knox et al. (2011) examined $\mathrm{E}_{2}$ levels and onset of menopause in 25000 women who were part of the C8 Health Project, a cohort of individuals who were exposed to perfluorocarbons due to contamination of drinking water in 2005/6. They reported an inverse relationship between perfluorooctane sulfonate and $\mathrm{E}_{2}$ in both peri-menopausal and menopausal groups (Knox et al. 2011), indicating a potential link to early menopause.

\section{Evidence that lifestyle factors can increase the influence of EDC on lifetime risk of developing reproductive tract cancers}

Obesity has been estimated to account for 39\% of endometrial cancer cases in European women (Bergstrom et al. 2001) and a strong linear association of BMI and endometrial cancer risk has been described (Lindemann et al. 2008). Increased BMI is also associated with increased risk of cancers of the ovary and cervix (Calle et al. 2003). Obesity is associated with increased inflammation, increased levels of oestrogens and abdominal adiposity is most strongly correlated with an increased risk of endometrial cancer (Canchola et al. 2010, Wallace et al. 2010). Obesity is also associated with increased risk of developing insulin resistance and type 2 diabetes (Kahn et al. 2006), which are associated with a threefold increased risk of endometrial cancer (Lindemann et al. 2008). Studies in mice based on neonatal administration of DES or genistein indicated that EDC exposure may also contribute to development of higher BMI, highlighting the potential for complex interactions between different risk factors (Newbold et al. 2005).

The aromatase gene is expressed in adipose tissue under the control of a promoter regulated by class 1 cytokines and TNF $\alpha$ (Simpson 2003). It has been reported that the capacity of adipose tissue, particularly in gluteal rather than abdominal depots, to produce oestrogen shows an age-dependent increase, being higher after menopause (Misso et al. 2005). Adipose tissue can act as a depot for EDCs and might therefore enhance exposure and risk of developing endometrial cancer in obese individuals due to bioaccumulation of lipophilic EDCs. In a study by Hardell et al. (2004) adipose tissue concentrations of polychlorinated biphenyls, hexachlorobenzene, $\mathrm{p}, \mathrm{p}^{\prime}$-DDE, chlordanes and PBBs were evaluated in a case-control study for endometrial cancer. The authors reported that while most odds ratios (OR) were close to unity, an increased OR was found for $\mathrm{p}, \mathrm{p}^{\prime}$-DDE, and OR was further increased in association with use of oestrogen-replacement therapy (Hardell et al. 2004). Researchers in Argentina recorded high levels of organochlorines including $\mathrm{p}, \mathrm{p}^{\prime}$-DDE in breast adipose tissue noting a significant correlation with BMI (Munoz-de-Toro et al. 2006). Interestingly, a previous study assessing serum http://erc.endocrinology-journals.org DOI: 10.1530/ERC-13-0342
(C) 2014 Society for Endocrinology Printed in Great Britain 
concentrations of organochlorine compounds found no increased risk for endometrial cancer (Sturgeon et al. 1998), highlighting the importance of assessing concentrations of EDCs within the adipose tissue itself.

Smoking is inversely associated with endometrial cancer risk (Weiderpass \& Baron 2001, Lindemann et al. 2008). This is thought to be due to the influence on metabolism of oestrogens. Cigarette smoking has been reported to promote 2-hydroxylation of $\mathrm{E}_{2}$ and diminish 16a-hydroxylation (Michnovicz et al. 1986), leading to formation of oestrogen metabolites that are less oestrogenic and do not stimulate the uterus (Martucci \& Fishman 1977).

Data related to the effects of alcohol on risk of endometrial cancers appear to be conflicting, with the EPIC study reporting no increased risk (Fedirko et al. 2013) while another using 26 years of follow-up data from the Nurses' Health Study indicated that moderate alcohol intake might be protective (Liu et al. 2013). To date, the effects of alcohol consumption on metabolism, bioaccumulation or activity of EDC have not been investigated.

\section{Summary and future perspectives}

Many hundreds of compounds with the potential to alter oestrogen-dependent signalling have been identified in our environment; ingestion via breast milk, food or water are key routes of exposure (Knox et al. 2011, Govarts et al. 2012). To date, the best evidence that EDC can have an adverse effect on reproductive health in women has come from follow-up on women exposed in utero to DES (DES daughters). Evidence from animal- and cell-based studies reporting that DES can alter expression of HOX genes that play a key role in regulation of Müllerian duct development as well as fertility in adulthood has offered one mechanism by which EDC may act to alter reproductive function. There has been intense interest in the potential for EDC to increase the risk of a range of cancers but establishing a causal link between exposure and disease has proved challenging. In utero exposure to EDC has also been linked with an increased likelihood of reduced birth weight as well as other features of the metabolic syndrome, including increased incidences of obesity and diabetes, which are risk factors for endometrial cancer (Govarts et al. 2012, Dossus et al. 2013). Epidemiological studies recording clear associations between breast and other cancers with occupational exposures are now offering new and exciting data sets with which to address the question of how exposure in adulthood can affect development or progression of malignancy (Brophy et al. 2012).
The female reproductive tract is exquisitely sensitive to the actions of oestrogens but other sex steroids including progestins and androgens also play critical roles, in part by modulating the potentially deleterious effects of oestrogens including excess proliferation (see above). It is notable that EDC such as BPA (Table 1) may act via more than one steroid receptor pathway (Lee et al. 2003). Recently, Teng et al. (2013) used a systematic screening approach to investigate the effects of BPA on ten different nuclear receptors including ER $\alpha$, AR, GR, LXR $\beta$, VDR and TR $\beta$, and demonstrated that BPA is an agonist of $\mathrm{ER} \alpha$ and an antagonist of AR but had no effect on other nuclear receptors (Teng et al. 2013). Our recent study reported that apoptosis or cell migration may be regulated by androgen-receptor-dependent mechanisms in the endometrium (Marshall et al. 2011). We speculate that EDC such as BPA that exhibit anti-androgen activity could alter processes known to play a role in cancer metastases. An array study conducted in rats identified a subset of genes that could respond to both androgens and oestrogens, with distinct but overlapping gene sets (Nantermet et al. 2005), emphasising the potential importance of EDC in mediating crosstalk between these signalling pathways. Studies in breast tissues indicated that AR-dependent signalling may have opposite effects in normal vs cancer tissue (Hickey et al. 2012), something that merits further investigation in the context of reproductive tract cancers. There has been interest in using androgens to treat a range of disorders in postmenopausal women and inclusion of androgens in HRT has been reported to have beneficial effects on endometrial tissue (Zang et al. 2007), although there is an ongoing concern about negative side effects and long-term studies are needed.

The expression of ER subtypes within target tissues is also likely to influence the effects of EDC. For example, co-expression of $\mathrm{ER} \beta$ with $\mathrm{ER} \alpha$ and consequent formation of $\mathrm{ER} \alpha$-ER $\beta$ heterodimers reduced $\mathrm{ER} \alpha$-driven transcription of some genes by competing for shared response elements (Charn et al. 2010). Furthermore, EDC such as phytoestrogens that demonstrate high affinity binding to ER $\beta$ may have a disproportionate effect on the function of endothelial and immune cells (Greaves et al. 2013), providing a potential link between EDC and the inflammatory processes known to contribute to the aetiology of endometrial cancers (Wallace et al. 2010).

Historically, the approach for investigating the effects of EDC on the reproductive tract has relied heavily on the 'one EDC', 'one disease' paradigm; however, focusing on the action of single EDC may be underestimating the risk from total exposure (Bergman et al. 2013). It has 
previously been reported that mixtures of EDCs that individually have no effect on ER act simultaneously to promote an agonist response when tested as a mixture (Tinwell \& Ashby 2004). Future studies will need to make more accurate measurements of body-wide concentrations of EDC and endogenous steroids using up-to-date methodology based on mass spectrometry (Tamae et al. 2013). One option being explored is the use of in silico methods for elucidating potential EDCs, including pharmacophore modelling and docking models (reviewed in Vuorinen et al. (2013)).

In summary, although the prevalence of female reproductive cancers is increasing, the evidence that EDC exposure in humans has a direct effect on the development of endometrial cancer is incomplete and confounded by factors such as increased rates of obesity. Evidence from animal models indicates that early developmental exposure to EDC increases the occurrence of reproductive cancers and that the trans-generational effects of EDC exposure (as described in DES animal models) may pose a risk for future generations. New insights await carefully controlled prospective data from EDC-exposed women and greater use of multidisciplinary systems modelling the effects of mixtures of putative EDC on the aetiology of different reproductive disorders and their relationships with whole-body physiology throughout the life course.

\section{Declaration of interest}

The authors declare that there is no conflict of interest that could be perceived as prejudicing the impartiality of the review.

\section{Funding}

Studies carried out in the author's laboratory were supported by MRC Programme Grant G1100356/1 to P T K Saunders.

\section{References}

Abraham GE 1974 Ovarian and adrenal contribution to peripheral androgens during the menstrual cycle. Journal of Clinical Endocrinology and Metabolism 39 340-346. (doi:10.1210/jcem-39-2-340)

Aghajanova L \& Giudice LC 2011 Effect of bisphenol A on human endometrial stromal fibroblasts in vitro. Reproductive BioMedicine Online 22 249-256. (doi:10.1016/j.rbmo.2010.12.007)

Akbas GE, Song J \& Taylor HS 2004 A HOXA10 estrogen response element (ERE) is differentially regulated by $17 \beta$-estradiol and diethylstilbestrol (DES). Journal of Molecular Biology 340 1013-1023. (doi:10.1016/j.jmb. 2004.05.052)

Allen NE, Key TJ, Dossus L, Rinaldi S, Cust A, Lukanova A, Peeters PH, Onland-Moret NC, Lahmann PH, Berrino F et al. 2008 Endogenous sex hormones and endometrial cancer risk in women in the European
Prospective Investigation into Cancer and Nutrition (EPIC). EndocrineRelated Cancer 15 485-497. (doi:10.1677/ERC-07-0064)

Alvarado-Cabrero I, Stolnicu S, Kiyokawa T, Yamada K, Nikaido T \& Santiago-Payan H 2013 Carcinoma of the fallopian tube: results of a multi-institutional retrospective analysis of 127 patients with evaluation of staging and prognostic factors. Annals of Diagnostic Pathology 17 159-164. (doi:10.1016/j.anndiagpath.2012.10.001)

Arcaro KF, Yi L, Seegal RF, Vakharia DD, Yang Y, Spink DC, Brosch K \& Gierthy JF 1999 2,2',6,6'-Tetrachlorobiphenyl is estrogenic in vitro and in vivo. Journal of Cellular Biochemistry 72 94-102. (doi:10.1002/ (SICI) 1097-4644(19990101)72:1 < 94::AID-JCB10 > 3.0.CO;2-Y)

Arem H, Park Y, Pelser C, Ballard-Barbash R, Irwin ML, Hollenbeck A, Gierach GL, Brinton LA, Pfeiffer RM \& Matthews CE 2013 Prediagnosis body mass index, physical activity, and mortality in endometrial cancer patients. Journal of the National Cancer Institute 105 342-349. (doi:10.1093/jnci/djs530)

Ashby J \& Tinwell H 1998 Uterotrophic activity of bisphenol A in the immature rat. Environmental Health Perspectives 106 719-720. (doi:10.1289/ehp.98106719)

Ashton KA, Proietto A, Otton G, Symonds I, McEvoy M, Attia J, Gilbert M, Hamann U \& Scott RJ 2009 Estrogen receptor polymorphisms and the risk of endometrial cancer. BJOG: an International Journal of Obstetrics and Gynaecology 116 1053-1061. (doi:10.1111/j.1471-0528.2009. 02185.x)

Barnes-Ellerbe S, Knudsen KE \& Puga A 2004 2,3,7,8-Tetrachlorodibenzop-dioxin blocks androgen-dependent cell proliferation of LNCaP cells through modulation of pRB phosphorylation. Molecular Pharmacology 66 502-511. (doi:10.1124/mol.104.000356)

Bektic J, Berger AP, Pfeil K, Dobler G, Bartsch G \& Klocker H 2004 Androgen receptor regulation by physiological concentrations of the isoflavonoid genistein in androgen-dependent LNCaP cells is mediated by estrogen receptor B. European Urology 45 245-251. (doi:10.1016/j.eururo.2003. 09.001)

Beral V, Bull D \& Reeves G 2005a Endometrial cancer and hormonereplacement therapy in the Million Women Study. Lancet 365 1543-1551. (doi:10.1016/S0140-6736(05)66455-0)

Beral V, Reeves G \& Banks E 2005b Current evidence about the effect of hormone replacement therapy on the incidence of major conditions in postmenopausal women. BJOG: an International Journal of Obstetrics and Gynaecology 112 692-695. (doi:10.1111/j.1471-0528.2005.00541.x)

Bergman L, Beelen ML, Gallee MP, Hollema H, Benraadt J \& van Leeuwen FE 2000 Risk and prognosis of endometrial cancer after tamoxifen for breast cancer. Comprehensive Cancer Centres' ALERT Group. Assessment of Liver and Endometrial cancer Risk following Tamoxifen. Lancet 356 881-887. (doi:10.1016/S0140-6736(00)02677-5)

Bergman A, Heindel JJ, Kasten T, Kidd KA, Jobling S, Neira M, Zoeller RT, Becher G, Bjerregaard P, Bornman R et al. 2013 The impact of endocrine disruption: a consensus statement on the state of the science. Environmental Health Perspectives 121 A104-A106. (doi:10.1289/ehp. 1205448)

Bergstrom A, Pisani P, Tenet V, Wolk A \& Adami HO 2001 Overweight as an avoidable cause of cancer in Europe. International Journal of Cancer 91 421-430. (doi:10.1002/1097-0215(200002)9999:9999<::AIDIJC1053 > 3.0.CO;2-T)

Bertazzi PA, Pesatori AC, Bernucci I, Landi MT \& Consonni D 1999 Dioxin exposure and human leukemias and lymphomas. Lessons from the Seveso accident and studies on industrial workers. Leukemia 13 (Suppl 1) S72-S74. (doi:10.1038/sj.leu.2401290)

Biesiada J, Porollo A, Velayutham P, Kouril M \& Meller J 2011 Survey of public domain software for docking simulations and virtual screening. Human Genomics 5 497-505. (doi:10.1186/1479-7364-5-5-497)

Blair RM, Fang H, Branham WS, Hass BS, Dial SL, Moland CL, Tong W, Shi L, Perkins R \& Sheehan DM 2000 The estrogen receptor relative binding affinities of 188 natural and xenochemicals: structural diversity of ligands. Toxicological Sciences 54 138-153. (doi:10.1093/toxsci/54.1.138) 
Blanck HM, Marcus M, Tolbert PE, Rubin C, Henderson AK, Hertzberg VS, Zhang RH \& Cameron L 2000 Age at menarche and tanner stage in girls exposed in utero and postnatally to polybrominated biphenyl. Epidemiology 11 641-647. (doi:10.1097/00001648-200011000-00005)

Block K, Kardana A, Igarashi P \& Taylor HS 2000 In utero diethylstilbestrol (DES) exposure alters Hox gene expression in the developing Müllerian system. FASEB Journal 14 1101-1108.

Bombail V, MacPherson S, Critchley HO \& Saunders PT 2008 Estrogen receptor related $\beta$ is expressed in human endometrium throughout the normal menstrual cycle. Human Reproduction 23 2782-2790. (doi:10.1093/humrep/den298)

Bombail V, Collins F, Brown P \& Saunders PT 2010 Modulation of ER $\alpha$ transcriptional activity by the orphan nuclear receptor ERR $\beta$ and evidence for differential effects of long- and short-form splice variants. Molecular and Cellular Endocrinology 314 53-61. (doi:10.1016/j.mce. 2009.09.007)

Bosch FX \& de Sanjose S 2007 The epidemiology of human papillomavirus infection and cervical cancer. Disease Markers 23 213-227. (doi:10.1155/2007/914823)

Brake T \& Lambert PF 2005 Estrogen contributes to the onset, persistence, and malignant progression of cervical cancer in a human papillomavirus-transgenic mouse model. PNAS 102 2490-2495. (doi:10.1073/ pnas.0409883102)

Bromer JG, Wu J, Zhou Y \& Taylor HS 2009 Hypermethylation of homeobox A10 by in utero diethylstilbestrol exposure: an epigenetic mechanism for altered developmental programming. Endocrinology 150 3376-3382. (doi:10.1210/en.2009-0071)

Bromer JG, Zhou Y, Taylor MB, Doherty L \& Taylor HS 2010 Bisphenol-A exposure in utero leads to epigenetic alterations in the developmental programming of uterine estrogen response. FASEB Journal $\mathbf{2 4}$ 2273-2280. (doi:10.1096/fj.09-140533)

Brophy JT, Keith MM, Watterson A, Park R, Gilbertson M, Maticka-Tyndale E, Beck M, Abu-Zahra H, Schneider K, Reinhartz A et al. 2012 Breast cancer risk in relation to occupations with exposure to carcinogens and endocrine disruptors: a Canadian case-control study. Environmental Health 11 87. (doi:10.1186/1476-069X-11-87)

Brotons JA, Olea-Serrano MF, Villalobos M, Pedraza V \& Olea N 1995 Xenoestrogens released from lacquer coatings in food cans. Environmental Health Perspectives 103 608-612. (doi:10.1289/ehp.95103608)

Bulun SE, Economos K, Miller D \& Simpson ER 1994 CYP19 (aromatase cytochrome P450) gene expression in human malignant endometrial tumors. Journal of Clinical Endocrinology and Metabolism 79 1831-1834. (doi:10.1210/jc.79.6.1831)

Bulun SE, Chen D, Lu M, Zhao H, Cheng Y, Demura M, Yilmaz B, Martin R, Utsunomiya H, Thung S et al. 2007 Aromatase excess in cancers of breast, endometrium and ovary. Journal of Steroid Biochemistry and Molecular Biology 106 81-96. (doi:10.1016/j.jsbmb.2007.05.027)

Buttke DE, Sircar K \& Martin C 2012 Exposures to endocrine-disrupting chemicals and age of menarche in adolescent girls in NHANES (2003-2008). Environmental Health Perspectives 120 1613-1618. (doi:10.1289/ehp.1104748)

Calle EE, Rodriguez C, Walker-Thurmond K \& Thun MJ 2003 Overweight, obesity, and mortality from cancer in a prospectively studied cohort of U.S. adults. New England Journal of Medicine 348 1625-1638. (doi:10.1056/NEJMoa021423)

Canchola AJ, Chang ET, Bernstein L, Largent JA, Reynolds P, Deapen D, Ursin G \& Horn-Ross PL 2010 Body size and the risk of endometrial cancer by hormone therapy use in postmenopausal women in the California Teachers Study cohort. Cancer Causes \& Control 21 1407-1416. (doi:10.1007/s10552-010-9568-8)

Ceccatelli R, Faass O, Schlumpf M \& Lichtensteiger W 2006 Gene expression and estrogen sensitivity in rat uterus after developmental exposure to the polybrominated diphenylether PBDE 99 and PCB. Toxicology 220 104-116. (doi:10.1016/j.tox.2005.12.004)

Cederquist K, Emanuelsson M, Goransson I, Holinski-Feder E, Muller-Koch Y, Golovleva I \& Gronberg H 2004 Mutation analysis of the MLH1, MSH2 and MSH6 genes in patients with double primary cancers of the colorectum and the endometrium: a population-based study in northern Sweden. International Journal of Cancer 109 370-376. (doi:10.1002/ijc.11718)

Charn TH, Liu ET, Chang EC, Lee YK, Katzenellenbogen JA \& Katzenellenbogen BS 2010 Genome-wide dynamics of chromatin binding of estrogen receptors $\alpha$ and $\beta$ : mutual restriction and competitive site selection. Molecular Endocrinology 24 47-59. (doi:10.1210/me.2009-0252)

Chung SH, Shin MK, Korach KS \& Lambert PF 2013 Requirement for stromal estrogen receptor $\alpha$ in cervical neoplasia. Hormones \& Cancer 4 50-59. (doi:10.1007/s12672-012-0125-7)

Colborn T, vom Saal FS \& Soto AM 1993 Developmental effects of endocrine-disrupting chemicals in wildlife and humans. Environmental Health Perspectives 101 378-384. (doi:10.1289/ehp.93101378)

Collins F, MacPherson S, Brown P, Bombail V, Williams AR, Anderson RA, Jabbour HN \& Saunders PT 2009 Expression of oestrogen receptors, $\mathrm{ER} \alpha, \mathrm{ER} \beta$, and $\mathrm{ER} \beta$ variants, in endometrial cancers and evidence that prostaglandin F may play a role in regulating expression of ER $\alpha$. BMC Cancer 9 330. (doi:10.1186/1471-2407-9-330)

Cooke GM, Price CA \& Oko RJ 1998 Effects of in utero and lactational exposure to 2,3,7,8-tetrachlorodibenzo-p-dioxin (TCDD) on serum androgens and steroidogenic enzyme activities in the male rat reproductive tract. Journal of Steroid Biochemistry and Molecular Biology 67 347-354. (doi:10.1016/S0960-0760(98)00127-7)

Couse JF \& Korach KS 2004 Estrogen receptor- $\alpha$ mediates the detrimental effects of neonatal diethylstilbestrol (DES) exposure in the murine reproductive tract. Toxicology 205 55-63. (doi:10.1016/j.tox. 2004.06.046)

Couse JF, Davis VL, Hanson RB, Jefferson WN, McLachlan JA, Bullock BC, Newbold RR \& Korach KS 1997 Accelerated onset of uterine tumors in transgenic mice with aberrant expression of the estrogen receptor after neonatal exposure to diethylstilbestrol. Molecular Carcinogenesis 19 236-242. (doi:10.1002/(SICI)1098-2744(199708)19:4<236:AID$\mathrm{MC} 4>3.0 . \mathrm{CO} ; 2-\mathrm{A})$

Couse JF, Dixon D, Yates M, Moore AB, Ma L, Maas R \& Korach KS 2001 Estrogen receptor- $\alpha$ knockout mice exhibit resistance to the developmental effects of neonatal diethylstilbestrol exposure on the female reproductive tract. Developmental Biology 238 224-238. (doi:10.1006/ dbio.2001.0413)

Crain DA, Janssen SJ, Edwards TM, Heindel J, Ho SM, Hunt P, Iguchi T, Juul A, McLachlan JA, Schwartz J et al. 2008 Female reproductive disorders: the roles of endocrine-disrupting compounds and developmental timing. Fertility and Sterility 90 911-940. (doi:10.1016/j. fertnstert.2008.08.067)

Cramer SF \& Patel A 1990 The frequency of uterine leiomyomas. American Journal of Clinical Pathology 94 435-438.

Critchley HO, Brenner RM, Henderson TA, Williams K, Nayak NR, Slayden OD, Millar MR \& Saunders PT 2001 Estrogen receptor $\beta$, but not estrogen receptor $\alpha$, is present in the vascular endothelium of the human and nonhuman primate endometrium. Journal of Clinical Endocrinology and Metabolism 86 1370-1378. (doi:10.1210/jc.86.3.1370)

Critchley HO, Henderson TA, Kelly RW, Scobie GS, Evans LR, Groome NP \& Saunders PT 2002 Wild-type estrogen receptor (ER $\beta 1)$ and the splice variant $(E R \beta c x / \beta 2)$ are both expressed within the human endometrium throughout the normal menstrual cycle. Journal of Clinical Endocrinology and Metabolism 87 5265-5273. (doi:10.1210/jc.2002-020502)

Cunha GR 1976 Stromal induction and specification of morphogenesis and cytodifferentiation of the epithelia of the Müllerian ducts and urogenital sinus during development of the uterus and vagina in mice. Journal of Experimental Zoology 196 361-370. (doi:10.1002/jez. 1401960310)

Daftary GS \& Taylor HS 2006 Endocrine regulation of HOX genes. Endocrine Reviews 27 331-355. (doi:10.1210/er.2005-0018)

Davis VL, Newbold RR, Couse JF, Rea SL, Gallagher KM, Hamilton KJ, Goulding EH, Jefferson W, Eddy EM, Bullock BC et al. 2012 Expression http://erc.endocrinology-journals.org DOI: 10.1530/ERC-13-0342
(C) 2014 Society for Endocrinology Printed in Great Britain 
of a dominant negative estrogen receptor $\alpha$ variant in transgenic mice accelerates uterine cancer induced by the potent estrogen diethylstilbestrol. Reproductive Toxicology 34 512-521. (doi:10.1016/j.reprotox. 2012.08.005)

De Coster S \& van Larebeke N 2012 Endocrine-disrupting chemicals: associated disorders and mechanisms of action. Journal of Environmental and Public Health 2012 713696. (doi:10.1155/2012/713696)

Diel P, Smolnikar K, Schulz T, Laudenbach-Leschowski U, Michna H \& Vollmer G 2001 Phytoestrogens and carcinogenesis-differential effects of genistein in experimental models of normal and malignant rat endometrium. Human Reproduction 16 997-1006. (doi:10.1093/ humrep/16.5.997)

Doll A, Abal M, Rigau M, Monge M, Gonzalez M, Demajo S, Colas E, Llaurado M, Alazzouzi H, Planaguma J et al. 2008 Novel molecular profiles of endometrial cancer-new light through old windows. Journal of Steroid Biochemistry and Molecular Biology 108 221-229. (doi:10.1016/j.jsbmb.2007.09.020)

Dossus L, Lukanova A, Rinaldi S, Allen N, Cust AE, Becker S, Tjonneland A, Hansen L, Overvad K, Chabbert-Buffet N et al. 2013 Hormonal, metabolic, and inflammatory profiles and endometrial cancer risk within the EPIC cohort - a factor analysis. American Journal of Epidemiology 177 787-799. (doi:10.1093/aje/kws309)

Dubeau L 2008 The cell of origin of ovarian epithelial tumours. Lancet Oncology 9 1191-1197. (doi:10.1016/S1470-2045(08)70308-5)

Dupont S, Krust A, Gansmuller A, Dierich A, Chambon P \& Mark M 2000 Effect of single and compound knockouts of estrogen receptors $\alpha(E R \alpha)$ and $\beta$ (ER $\beta$ ) on mouse reproductive phenotypes. Development 127 4277-4291.

van Duursen MBM, Sanderson JT, van der Bruggen M, van der Linden J \& van den Berg M 2003 Effects of several dioxin-like compounds on estrogen metabolism in the malignant MCF-7 and nontumorigenic MCF-10A human mammary epithelial cell lines. Toxicology and Applied Pharmacology 190 241-250. (doi:10.1016/S0041-008X(03)00166-2)

Ehrlich S, Williams PL, Hauser R, Missmer SA, Peretz J, Calafat AM \& Flaws JA 2013 Urinary bisphenol A concentrations and cytochrome P450 19 A1 (Cyp19) gene expression in ovarian granulosa cells: an in vivo human study. Reproductive Toxicology 42C 18-23. (doi:10.1016/j.reprotox.2013.06.071)

Emons G, Fleckenstein G, Hinney B, Huschmand A \& Heyl W 2000 Hormonal interactions in endometrial cancer. Endocrine-Related Cancer 7 227-242. (doi:10.1677/erc.0.0070227)

Fang H, Tong W, Shi LM, Blair R, Perkins R, Branham W, Hass BS, Xie Q Dial SL, Moland CL et al. 2001 Structure-activity relationships for a large diverse set of natural, synthetic, and environmental estrogens. Chemical Research in Toxicology 14 280-294. (doi:10.1021/tx000208y)

Fang H, Tong W, Branham WS, Moland CL, Dial SL, Hong H, Xie Q, Perkins R, Owens W \& Sheehan DM 2003 Study of 202 natural, synthetic, and environmental chemicals for binding to the androgen receptor. Chemical Research in Toxicology 16 1338-1358. (doi:10.1021/tx030011g)

Faqi AS \& Chahoud I 1998 Antiestrogenic effects of low doses of 2,3,7,8TCDD in offspring of female rats exposed throughout pregnancy and lactation. Bulletin of Environmental Contamination and Toxicology $\mathbf{6 1}$ 462-469. (doi:10.1007/s001289900785)

Fedirko V, Jenab M, Rinaldi S, Biessy C, Allen NE, Dossus L, Onland-Moret NC, Schutze M, Tjonneland A, Hansen L et al. 2013 Alcohol drinking and endometrial cancer risk in the European Prospective Investigation into Cancer and Nutrition (EPIC) study. Annals of Epidemiology 23 93-98. (doi:10.1016/j.annepidem.2012.11.009)

Fei X, Chung H \& Taylor HS 2005 Methoxychlor disrupts uterine Hoxa10 gene expression. Endocrinology 146 3445-3451. (doi:10.1210/ en.2005-0341)

Flesken-Nikitin A, Hwang CI, Cheng CY, Michurina TV, Enikolopov G \& Nikitin AY 2013 Ovarian surface epithelium at the junction area contains a cancer-prone stem cell niche. Nature 495 241-245. (doi:10.1038/nature11979)
Fowler PA, Anderson RA, Saunders PT, Kinnell H, Mason JI, Evans DB, Bhattacharya S, Flannigan S, Franks S, Monteiro A et al. 2011 Development of steroid signaling pathways during primordial follicle formation in the human fetal ovary. Journal of Clinical Endocrinology and Metabolism 96 1754-1762. (doi:10.1210/jc.2010-2618)

Freyberger A \& Ahr H-J 2004 Development and standardization of a simple binding assay for the detection of compounds with affinity for the androgen receptor. Toxicology 195 113-126. (doi:10.1016/j.tox.2003. 09.008)

Frigo DE, Burow ME, Mitchell KA, Chiang TC \& McLachlan JA 2002 DDT and its metabolites alter gene expression in human uterine cell lines through estrogen receptor-independent mechanisms. Environmental Health Perspectives 110 1239-1245. (doi:10.1289/ehp.021101239)

Gaido KW, Leonard LS, Lovell S, Gould JC, Babai D, Portier CJ \& McDonnell DP 1997 Evaluation of chemicals with endocrine modulating activity in a yeast-based steroid hormone receptor gene transcription assay. Toxicology and Applied Pharmacology 143 205-212. (doi:10.1006/taap.1996.8069)

Gibson DA \& Saunders PT 2012 Estrogen dependent signaling in reproductive tissues - a role for estrogen receptors and estrogen related receptors. Molecular and Cellular Endocrinology 348 361-372. (doi:10.1016/j.mce.2011.09.026)

Gierthy JF, Spink BC, Figge HL, Pentecost BT \& Spink DC 1996 Effects of 2,3,7,8-tetrachlorodibenzo-p-dioxin, 12-O-tetradecanoylphorbol13 -acetate and $17 \beta$-estradiol on estrogen receptor regulation in MCF-7 human breast cancer cells. Journal of Cellular Biochemistry 60 173-184. (doi:10.1002/(SICI) 1097-4644(19960201)60:2 <173::AID-JCB2 > 3.0. $\mathrm{CO} ; 2-\mathrm{U})$

Giguere V 2002 To ERR in the estrogen pathway. Trends in Endocrinology and Metabolism 13 220-225. (doi:10.1016/S1043-2760(02)00592-1)

Goodfellow PJ, Buttin BM, Herzog TJ, Rader JS, Gibb RK, Swisher E, Look K, Walls KC, Fan MY \& Mutch DG 2003 Prevalence of defective DNA mismatch repair and MSH6 mutation in an unselected series of endometrial cancers. PNAS 100 5908-5913. (doi:10.1073/pnas. 1030231100)

Gore AC, Walker DM, Zama AM, Armenti AE \& Uzumcu M 2011 Early life exposure to endocrine-disrupting chemicals causes lifelong molecular reprogramming of the hypothalamus and premature reproductive aging. Molecular Endocrinology 25 2157-2168. (doi:10.1210/ me.2011-1210)

Govarts E, Nieuwenhuijsen M, Schoeters G, Ballester F, Bloemen K, de Boer M, Chevrier C, Eggesbo M, Guxens M, Kramer U et al. 2012 Birth weight and prenatal exposure to polychlorinated biphenyls (PCBs) and dichlorodiphenyldichloroethylene (DDE): a meta-analysis within 12 European Birth Cohorts. Environmental Health Perspectives 120 162-170. (doi:10.1289/ehp.1103767)

Greaves E, Collins F, Critchley HO \& Saunders PT 2013 ERß-dependent effects on uterine endothelial cells are cell specific and mediated via Sp1. Human Reproduction 28 2490-2501. (doi:10.1093/humrep/det235)

Grochowalski A, Chrzaszcz R, Pieklo R \& Gregoraszczuk EL 2001 Estrogenic and antiestrogenic effect of in vitro treatment of follicular cells with 2,3,7,8-tetrachlorodibenzo-p-dioxin. Chemosphere 43 823-827. (doi:10.1016/S0045-6535(00)00440-9)

Gruber CJ, Tschugguel W, Schneeberger C \& Huber JC 2002 Production and actions of estrogens. New England Journal of Medicine 346 340-352. (doi:10.1056/NEJMra000471)

Hale GE, Hughes CL \& Cline JM 2002 Endometrial cancer: hormonal factors, the perimenopausal "window of risk," and isoflavones. Journal of Clinical Endocrinology and Metabolism 87 3-15. (doi:10.1210/jc.87.1.3)

Hall JM \& McDonnell DP 1999 The estrogen receptor $\beta$-isoform (ER $\beta$ ) of the human estrogen receptor modulates ER $\alpha$ transcriptional activity and is a key regulator of the cellular response to estrogens and antiestrogens. Endocrinology 140 5566-5578. (doi:10.1210/en.140.12.5566)

Hall JM, Couse JF \& Korach KS 2001 The multifaceted mechanisms of estradiol and estrogen receptor signaling. Journal of Biological Chemistry 276 36869-36872. (doi:10.1074/jbc.R100029200) 
Hardell L, van Bavel B, Lindstrom G, Bjornfoth H, Orgum P, Carlberg M, Sorensen CS \& Graflund M 2004 Adipose tissue concentrations of $\mathrm{p}, \mathrm{p}^{\prime}$-DDE and the risk for endometrial cancer. Gynecologic Oncology 95 706-711. (doi:10.1016/j.ygyno.2004.08.022)

Harris HA, Katzenellenbogen JA \& Katzenellenbogen BS 2002 Characterization of the biological roles of the estrogen receptors, ER $\alpha$ and ER $\beta$, in estrogen target tissues in vivo through the use of an $\mathrm{ER} \alpha$-selective ligand. Endocrinology 143 4172-4177. (doi:10.1210/en.2002-220403)

Heldring N, Pike A, Andersson S, Matthews J, Cheng G, Hartman J, Tujague M, Strom A, Treuter E, Warner M et al. 2007 Estrogen receptors: how do they signal and what are their targets. Physiological Reviews 87 905-931. (doi:10.1152/physrev.00026.2006)

Henderson TA, Saunders PT, Moffett-King A, Groome NP \& Critchley HO 2003 Steroid receptor expression in uterine natural killer cells. Journal of Clinical Endocrinology and Metabolism 88 440-449. (doi:10.1210/ jc.2002-021174)

Herbst AL, Ulfelder H \& Poskanzer DC 1971 Adenocarcinoma of the vagina. Association of maternal stilbestrol therapy with tumor appearance in young women. New England Journal of Medicine 284 878-881. (doi:10.1056/NEJM197104222841604)

Hickey TE, Robinson JL, Carroll JS \& Tilley WD 2012 Minireview: the androgen receptor in breast tissues: growth inhibitor, tumor suppressor, oncogene? Molecular Endocrinology 26 1252-1267. (doi:10.1210/me.2012-1107)

Hiroi H, Tsutsumi O, Takeuchi T, Momoeda M, Ikezuki Y, Okamura A, Yokota H \& Taketani Y 2004 Differences in serum bisphenol a concentrations in premenopausal normal women and women with endometrial hyperplasia. Endocrine Journal 51 595-600. (doi:10.1507/ endocrj.51.595)

Hoover RN, Hyer M, Pfeiffer RM, Adam E, Bond B, Cheville AL, Colton T, Hartge P, Hatch EE, Herbst AL et al. 2011 Adverse health outcomes in women exposed in utero to diethylstilbestrol. New England Journal of Medicine 365 1304-1314. (doi:10.1056/NEJMoa1013961)

Horne AW, King AE, Shaw E, McDonald SE, Williams AR, Saunders PT \& Critchley HO 2009 Attenuated sex steroid receptor expression in fallopian tube of women with ectopic pregnancy. Journal of Clinical Endocrinology and Metabolism 94 5146-5154. (doi:10.1210/ jc.2009-1476)

Horn-Ross PL, John EM, Canchola AJ, Stewart SL \& Lee MM 2003 Phytoestrogen intake and endometrial cancer risk. Journal of the National Cancer Institute 95 1158-1164. (doi:10.1093/jnci/djg015)

Hwang LY, Ma Y, Benningfield SM, Clayton L, Hanson EN, Jay J, Jonte J, Godwin de Medina C \& Moscicki AB 2009 Factors that influence the rate of epithelial maturation in the cervix in healthy young women. Journal of Adolescent Health 44 103-110. (doi:10.1016/j.jadohealth. 2008.10.006)

Jefferson WN, Padilla-Banks E, Clark G \& Newbold RR 2002 Assessing estrogenic activity of phytochemicals using transcriptional activation and immature mouse uterotrophic responses. Journal of Chromatography. B, Analytical Technologies in the Biomedical and Life Sciences $\mathbf{7 7 7}$ 179-189. (doi:10.1016/S1570-0232(02)00493-2)

Johannisson E, Landgren BM, Rohr HP \& Diczfalusy E 1987 Endometrial morphology and peripheral hormone levels in women with regular menstrual cycles. Fertility and Sterility $\mathbf{4 8} 401-408$.

Jordan VC 2003 Tamoxifen: a most unlikely pioneering medicine. Nature Reviews. Drug Discovery 2 205-213. (doi:10.1038/nrd1031)

Kabbarah O, Mallon MA, Pfeifer JD, Edelmann W, Kucherlapati R \& Goodfellow PJ 2003 A panel of repeat markers for detection of microsatellite instability in murine tumors. Molecular Carcinogenesis 38 155-159. (doi:10.1002/mc.10157)

Kabbarah O, Mallon MA, Pfeifer JD \& Goodfellow PJ 2006 Transcriptional profiling endometrial carcinomas microdissected from DES-treated mice identifies changes in gene expression associated with estrogenic tumor promotion. International Journal of Cancer 119 1843-1849. (doi:10.1002/ijc.22063)
Kahn SE, Hull RL \& Utzschneider KM 2006 Mechanisms linking obesity to insulin resistance and type 2 diabetes. Nature $\mathbf{4 4 4} 840-846$. (doi:10.1038/nature05482)

Kang K-S, Kim H-S, Ryu D-Y, Che J-H \& Lee Y-S 2000 Immature uterotrophic assay is more sensitive than ovariectomized uterotrophic assay for the detection of estrogenicity of p-nonylphenol in SpragueDawley rats. Toxicology Letters 118 109-115. (doi:10.1016/S03784274(00)00272-1)

Kedar RP, Bourne TH, Powles TJ, Collins WP, Ashley SE, Cosgrove DO \& Campbell S 1994 Effects of tamoxifen on uterus and ovaries of postmenopausal women in a randomised breast cancer prevention trial. Lancet 343 1318-1321. (doi:10.1016/S0140-6736(94)92466-X)

Kelce WR, Stone CR, Laws SC, Gray LE, Kemppainen JA \& Wilson EM 1995 Persistent DDT metabolite $\mathrm{p}, \mathrm{p}^{\prime}$-DDE is a potent androgen receptor antagonist. Nature 375 581-585. (doi:10.1038/375581a0)

Kerdivel G, Le Guevel R, Habauzit D, Brion F, Ait-Aissa S \& Pakdel F 2013 Estrogenic potency of benzophenone UV filters in breast cancer cells: proliferative and transcriptional activity substantiated by docking analysis. PLoS ONE 8 e60567. (doi:10.1371/journal.pone.0060567)

Key TJ \& Pike MC 1988 The dose-effect relationship between 'unopposed' oestrogens and endometrial mitotic rate: its central role in explaining and predicting endometrial cancer risk. British Journal of Cancer $\mathbf{5 7}$ 205-212. (doi:10.1038/bjc.1988.44)

Kim HS, Shin JH, Moon HJ, Kang IH, Kim TS, Kim IY, Seok JH, Pyo MY \& Han SY 2002 Comparative estrogenic effects of $p$-nonylphenol by 3-day uterotrophic assay and female pubertal onset assay. Reproductive Toxicology 16 259-268. (doi:10.1016/S0890-6238(02)00028-X)

Klinge CM, Kaur K \& Swanson HI 2000 The aryl hydrocarbon receptor interacts with estrogen receptor $\alpha$ and orphan receptors COUP-TFI and ERR $\alpha 1$. Archives of Biochemistry and Biophysics 373 163-174. (doi:10.1006/abbi.1999.1552)

Klotz DM, Beckman BS, Hill SM, McLachlan JA, Walters MR \& Arnold SF 1996 Identification of environmental chemicals with estrogenic activity using a combination of in vitro assays. Environmental Health Perspectives 104 1084-1089. (doi:10.1289/ehp.961041084)

Klotz DM, Hewitt SC, Korach KS \& Diaugustine RP 2000 Activation of a uterine insulin-like growth factor I signaling pathway by clinical and environmental estrogens: requirement of estrogen receptor- $\alpha$. Endocrinology 141 3430-3439. (doi:10.1210/en.141.9.3430)

Knox SS, Jackson T, Javins B, Frisbee SJ, Shankar A \& Ducatman AM 2011 Implications of early menopause in women exposed to perfluorocarbons. Journal of Clinical Endocrinology and Metabolism 96 1747-1753. (doi:10.1210/jc.2010-2401)

Kogevinas M 2001 Human health effects of dioxins: cancer, reproductive and endocrine system effects. Human Reproduction Update 7 331-339. (doi:10.1093/humupd/7.3.331)

Kogevinas M, Becher H, Benn T, Bertazzi PA, Boffetta P, Bueno-de-Mesquita HB, Coggon D, Colin D, Flesch-Janys D, Fingerhut M et al. 1997 Cancer mortality in workers exposed to phenoxy herbicides, chlorophenols, and dioxins. An expanded and updated international cohort study. American Journal of Epidemiology 145 1061-1075. (doi:10.1093/oxfordjournals.aje. a009069)

Krishnan AV, Stathis P, Permuth SF, Tokes L \& Feldman D 1993 Bisphenol-A: an estrogenic substance is released from polycarbonate flasks during autoclaving. Endocrinology 132 2279-2286. (doi:10.1210/en.132.6.2279)

Kuiper GG, Lemmen JG, Carlsson B, Corton JC, Safe SH, van der Saag PT, van der Burg B \& Gustafsson JA 1998 Interaction of estrogenic chemicals and phytoestrogens with estrogen receptor $\beta$. Endocrinology 139 4252-4263. (doi:10.1210/en.139.10.4252)

Kunz PY \& Fent K 2006a Estrogenic activity of UV filter mixtures. Toxicology and Applied Pharmacology 217 86-99. (doi:10.1016/j.taap.2006.07.014)

Kunz PY \& Fent K 2006 $b$ Multiple hormonal activities of UV filters and comparison of in vivo and in vitro estrogenic activity of ethyl-4aminobenzoate in fish. Aquatic Toxicology 79 305-324. (doi:10.1016/ j.aquatox.2006.06.016) 
Kwekel JC, Forgacs AL, Burgoon LD, Williams KJ \& Zacharewski TR 2009 Tamoxifen-elicited uterotrophy: cross-species and cross-ligand analysis of the gene expression program. BMC Medical Genomics 219. (doi:10.1186/1755-8794-2-19)

Lacey JV Jr, Mink PJ, Lubin JH, Sherman ME, Troisi R, Hartge P, Schatzkin A $\&$ Schairer C 2002 Menopausal hormone replacement therapy and risk of ovarian cancer. Journal of the American Medical Association $\mathbf{2 8 8}$ 334-341. (doi:10.1001/jama.288.3.334)

La Vecchia C, Tavani A, Franceschi S \& Parazzini F 1996 Oral contraceptives and cancer. A review of the evidence. Drug Safety 14 260-272. (doi:10.2165/00002018-199614040-00006)

Lee HJ, Chattopadhyay S, Gong EY, Ahn RS \& Lee K 2003 Antiandrogenic effects of bisphenol A and nonylphenol on the function of androgen receptor. Toxicological Sciences 75 40-46. (doi:10.1093/toxsci/kfg150)

Li S, Washburn KA, Moore R, Uno T, Teng C, Newbold RR, McLachlan JA \& Negishi M 1997 Developmental exposure to diethylstilbestrol elicits demethylation of estrogen-responsive lactoferrin gene in mouse uterus. Cancer Research $\mathbf{5 7}$ 4356-4359.

Li S, Hansman R, Newbold R, Davis B, McLachlan JA \& Barrett JC 2003 Neonatal diethylstilbestrol exposure induces persistent elevation of c-fos expression and hypomethylation in its exon-4 in mouse uterus. Molecular Carcinogenesis 38 78-84. (doi:10.1002/mc.10147)

Li X, Ye L, Wang X, Liu H, Qian X, Zhu Y \& Yu H 2012a Molecular docking, molecular dynamics simulation, and structure-based 3D-QSAR studies on estrogenic activity of hydroxylated polychlorinated biphenyls. Science of the Total Environment 441 230-238. (doi:10.1016/j.scitotenv. 2012.08.072)

Li Y, Burns KA, Arao Y, Luh CJ \& Korach KS 2012b Differential estrogenic actions of endocrine-disrupting chemicals bisphenol A, bisphenol AF, and zearalenone through estrogen receptor $\alpha$ and $\beta$ in vitro. Environmental Health Perspectives 120 1029-1035. (doi:10.1289/ehp.1104689)

Li Y, Luh CJ, Burns KA, Arao Y, Jiang Z, Teng CT, Tice RR \& Korach KS 2013 Endocrine-disrupting chemicals (EDCs): in vitro mechanism of estrogenic activation and differential effects on ER target genes. Environmental Health Perspectives 121 459-466, 466e451-456. (doi:10.1289/ ehp.1205951)

Lindemann K, Vatten LJ, Ellstrom-Engh M \& Eskild A 2008 Body mass, diabetes and smoking, and endometrial cancer risk: a follow-up study. British Journal of Cancer 98 1582-1585. (doi:10.1038/sj.bjc.6604313)

Liu JJ, Hazra A, Giovannucci E, Hankinson SE, Rosner B \& De Vivo I 2013 One-carbon metabolism factors and endometrial cancer risk. British Journal of Cancer 108 183-187. (doi:10.1038/bjc.2012.534)

Lubahn DB, Moyer JS, Golding TS, Couse JF, Korach KS \& Smithies O 1993 Alteration of reproductive function but not prenatal sexual development after insertional disruption of the mouse estrogen receptor gene. PNAS 90 11162-11166. (doi:10.1073/pnas.90.23.11162)

Markey CM, Michaelson CL, Veson EC, Sonnenschein C \& Soto AM 2001 The mouse uterotrophic assay: a reevaluation of its validity in assessing the estrogenicity of bisphenol A. Environmental Health Perspectives 109 55-60. (doi:10.1289/ehp.0110955)

Marshall E, Lowrey J, MacPherson S, Maybin JA, Collins F, Critchley HO \& Saunders PT 2011 In silico analysis identifies a novel role for androgens in the regulation of human endometrial apoptosis. Journal of Clinical Endocrinology and Metabolism 96 E1746-E1755. (doi:10.1210/ jc. 2011-0272)

Martucci C \& Fishman J 1977 Direction of estradiol metabolism as a control of its hormonal action - uterotrophic activity of estradiol metabolites. Endocrinology 101 1709-1715. (doi:10.1210/endo-101-6-1709)

Masuyama H, Hiramatsu Y, Kodama J \& Kudo T 2003 Expression and potential roles of pregnane $\mathrm{X}$ receptor in endometrial cancer. Journal of Clinical Endocrinology and Metabolism 88 4446-4454. (doi:10.1210/ jc.2003-030203)

Masuyama H, Nakatsukasa H, Takamoto N \& Hiramatsu Y 2007 Downregulation of pregnane $\mathrm{X}$ receptor contributes to cell growth inhibition and apoptosis by anticancer agents in endometrial cancer cells. Molecular Pharmacology 72 1045-1053. (doi:10.1124/mol.107.037937)
Matsushima A, Kakuta Y, Teramoto T, Koshiba T, Liu X, Okada H, Tokunaga T, Kawabata S, Kimura M \& Shimohigashi Y 2007 Structural evidence for endocrine disruptor bisphenol A binding to human nuclear receptor ERR $\gamma$. Journal of Biochemistry 142 517-524. (doi:10.1093/jb/mvm158)

Matthews J \& Gustafsson JA 2003 Estrogen signaling: a subtle balance between ER $\alpha$ and ER $\beta$. Molecular Interventions 3 281-292. (doi:10.1124/ mi.3.5.281)

Michnovicz JJ, Hershcopf RJ, Naganuma H, Bradlow HL \& Fishman J 1986 Increased 2-hydroxylation of estradiol as a possible mechanism for the anti-estrogenic effect of cigarette smoking. New England Journal of Medicine 315 1305-1309. (doi:10.1056/NEJM198611203152101)

Miller KP, Borgeest C, Greenfeld C, Tomic D \& Flaws JA 2004 In utero effects of chemicals on reproductive tissues in females. Toxicology and Applied Pharmacology 198 111-131. (doi:10.1016/j.taap.2003.07.016)

Mimura J \& Fujii-Kuriyama Y 2003 Functional role of AhR in the expression of toxic effects by TCDD. Biochimica et Biophysica Acta 1619 263-268. (doi:10.1016/S0304-4165(02)00485-3)

Misso ML, Jang C, Adams J, Tran J, Murata Y, Bell R, Boon WC, Simpson ER $\&$ Davis SR 2005 Adipose aromatase gene expression is greater in older women and is unaffected by postmenopausal estrogen therapy. Menopause 12 210-215. (doi:10.1097/00042192-200512020-00016)

Moore JT, McKee DD, Slentz-Kesler K, Moore LB, Jones SA, Horne EL, Su JL, Kliewer SA, Lehmann JM \& Willson TM 1998 Cloning and characterization of human estrogen receptor $\beta$ isoforms. Biochemical and Biophysical Research Communications 247 75-78. (doi:10.1006/bbrc. 1998.8738)

Morito K, Hirose T, Kinjo J, Hirakawa T, Okawa M, Nohara T, Ogawa S, Inoue $S$, Muramatsu M \& Masamune Y 2001 Interaction of phytoestrogens with estrogen receptors $\alpha$ and $\beta$. Biological \& Pharmaceutical Bulletin 24 351-356. (doi:10.1248/bpb.24.351)

Moriyama K, Tagami T, Akamizu T, Usui T, Saijo M, Kanamoto N, Hataya Y, Shimatsu A, Kuzuya H \& Nakao K 2002 Thyroid hormone action is disrupted by bisphenol A as an antagonist. Journal of Clinical Endocrinology and Metabolism 87 5185-5190. (doi:10.1210/jc.2002020209)

Munoz-de-Toro M, Beldomenico HR, Garcia SR, Stoker C, De Jesus JJ, Beldomenico PM, Ramos JG \& Luque EH 2006 Organochlorine levels in adipose tissue of women from a littoral region of Argentina. Environmental Research 102 107-112. (doi:10.1016/j.envres.2005. 12.017)

Mutter GL, Lin MC, Fitzgerald JT, Kum JB, Baak JP, Lees JA, Weng LP \& Eng C 2000 Altered PTEN expression as a diagnostic marker for the earliest endometrial precancers. Journal of the National Cancer Institute 92 924-930. (doi:10.1093/jnci/92.11.924)

Nagel SC, Hagelbarger JL \& McDonnell DP 2001 Development of an ER action indicator mouse for the study of estrogens, selective ER modulators (SERMs), and xenobiotics. Endocrinology 142 4721-4728. (doi:10.1210/en.142.11.4721)

Nair HB, Luthra R, Kirma N, Liu YG, Flowers L, Evans D \& Tekmal RR 2005 Induction of aromatase expression in cervical carcinomas: effects of endogenous estrogen on cervical cancer cell proliferation. Cancer Research 65 11164-11173. (doi:10.1158/0008-5472.CAN-05-1087)

Nantermet PV, Masarachia P, Gentile MA, Pennypacker B, Xu J, Holder D, Gerhold D, Towler D, Schmidt A, Kimmel DB et al. 2005 Androgenic induction of growth and differentiation in the rodent uterus involves the modulation of estrogen-regulated genetic pathways. Endocrinology 146 564-578. (doi:10.1210/en.2004-1132)

Newbold RR, Bullock BC \& McLachlan JA 1990 Uterine adenocarcinoma in mice following developmental treatment with estrogens: a model for hormonal carcinogenesis. Cancer Research 50 7677-7681.

Newbold RR, Hanson RB, Jefferson WN, Bullock BC, Haseman J \& McLachlan JA 1998 Increased tumors but uncompromised fertility in the female descendants of mice exposed developmentally to diethylstilbestrol. Carcinogenesis 19 1655-1663. (doi:10.1093/carcin/19.9. 1655) http://erc.endocrinology-journals.org DOI: 10.1530/ERC-13-0342 
Newbold RR, Padilla-Banks E, Snyder RJ \& Jefferson WN 2005 Developmental exposure to estrogenic compounds and obesity. Birth Defects Research. Part A, Clinical and Molecular Teratology 73 478-480. (doi:10.1002/bdra.20147)

Newbold RR, Jefferson WN, Grissom SF, Padilla-Banks E, Snyder RJ \& Lobenhofer EK 2007 Developmental exposure to diethylstilbestrol alters uterine gene expression that may be associated with uterine neoplasia later in life. Molecular Carcinogenesis 46 783-796. (doi:10.1002/mc.20308)

Nilsson S, Makela S, Treuter E, Tujague M, Thomsen J, Andersson G, Enmark E, Pettersson K, Warner M \& Gustafsson JA 2001 Mechanisms of estrogen action. Physiological Reviews 81 1535-1565.

Ohta R, Takagi A, Ohmukai H, Marumo H, Ono A, Matsushima Y, Inoue T, Ono H \& Kanno J 2012 Ovariectomized mouse uterotrophic assay of 36 chemicals. Journal of Toxicological Sciences 37 879-889. (doi:10.2131/ jts.37.879)

Ohtake F, Takeyama K, Matsumoto T, Kitagawa H, Yamamoto Y, Nohara K, Tohyama C, Krust A, Mimura J, Chambon P et al. 2003 Modulation of oestrogen receptor signalling by association with the activated dioxin receptor. Nature 423 545-550. (doi:10.1038/nature01606)

Ouyang F, Perry MJ, Venners SA, Chen C, Wang B, Yang F, Fang Z, Zang T, Wang L, Xu X et al. 2005 Serum DDT, age at menarche, and abnormal menstrual cycle length. Occupational and Environmental Medicine 62 878-884. (doi:10.1136/oem.2005.020248)

Paige LA, Christensen DJ, Gron H, Norris JD, Gottlin EB, Padilla KM, Chang CY, Ballas LM, Hamilton PT, McDonnell DP et al. 1999 Estrogen receptor (ER) modulators each induce distinct conformational changes in ER $\alpha$ and ER $\beta$. PNAS 96 3999-4004. (doi:10.1073/ pnas.96.7.3999)

Papaconstantinou AD, Umbreit TH, Fisher BR, Goering PL, Lappas NT \& Brown KM 2000 Bisphenol A-induced increase in uterine weight and alterations in uterine morphology in ovariectomized B6C3F1 mice: role of the estrogen receptor. Toxicological Sciences 56 332-339. (doi:10.1093/toxsci/56.2.332)

Paruthiyil S, Cvoro A, Zhao X, Wu Z, Sui Y, Staub RE, Baggett S, Herber CB, Griffin C, Tagliaferri M et al. 2009 Drug and cell type-specific regulation of genes with different classes of estrogen receptor $\beta$-selective agonists. PLOS ONE 4 e6271. (doi:10.1371/journal.pone.0006271)

Pasqualini JR, Cornier E, Grenier J, Vella C, Schatz B \& Netter A 1990 Effect of decapeptyl, an agonistic analog of gonadotropin-releasing hormone on estrogens, estrogen sulfates, and progesterone receptors in leiomyoma and myometrium. Fertility and Sterility 53 1012-1017.

Pellacani C, Buschini A, Galati S, Mussi F, Franzoni S \& Costa LG 2012 Evaluation of DNA damage induced by 2 polybrominated diphenyl ether flame retardants (BDE-47 and BDE-209) in SK-N-MC cells. International Journal of Toxicology 31 372-379. (doi:10.1177) 1091581812449663)

Peretz J, Gupta RK, Singh J, Hernandez-Ochoa I \& Flaws JA 2011 Bisphenol A impairs follicle growth, inhibits steroidogenesis, and downregulates rate-limiting enzymes in the estradiol biosynthesis pathway. Toxicological Sciences 119 209-217. (doi:10.1093/toxsci/kfq319)

Pike AC, Brzozowski AM, Hubbard RE, Bonn T, Thorsell AG, Engstrom O, Ljunggren J, Gustafsson JA \& Carlquist M 1999 Structure of the ligandbinding domain of oestrogen receptor $\beta$ in the presence of a partial agonist and a full antagonist. EMBO Journal 18 4608-4618. (doi:10.1093/emboj/18.17.4608)

Ponzo OJ \& Silvia C 2013 Evidence of reproductive disruption associated with neuroendocrine changes induced by UV-B filters, phtalates and nonylphenol during sexual maturation in rats of both gender. Toxicology 311 41-51. (doi:10.1016/j.tox.2013.05.014)

Punyadeera C, Dunselman G, Marbaix E, Kamps R, Galant C, Nap A, Goeij A, Ederveen A \& Groothuis P 2004 Triphasic pattern in the ex vivo response of human proliferative phase endometrium to oestrogens. Journal of Steroid Biochemistry and Molecular Biology 92 175-185. (doi:10.1016/j.jsbmb.2004.06.005)
Purdie DM \& Green AC 2001 Epidemiology of endometrial cancer. Best Practice \& Research. Clinical Obstetrics \& Gynaecology 15 341-354. (doi:10.1053/beog.2000.0180)

Rinaldi S, Plummer M, Biessy C, Castellsague X, Overvad K, Kruger Kjaer S, Tjonneland A, Clavel-Chapelon F, Chabbert-Buffet N, Mesrine S et al. 2011 Endogenous sex steroids and risk of cervical carcinoma: results from the EPIC study. Cancer Epidemiology, Biomarkers \& Prevention 20 2532-2540. (doi:10.1158/1055-9965.EPI-11-0753)

Rodriguez Y, Baez D, de Oca FM, Garcia C, Dorta I, Reyes R, Valladares F, Almeida TA \& Bello AR 2011 Comparative analysis of the ER $\alpha / \mathrm{ER} \beta$ ratio and neurotensin and its high-affinity receptor in myometrium, uterine leiomyoma, atypical leiomyoma, and leiomyosarcoma. International Journal of Gynecological Pathology 30 354-363. (doi:10.1097/PGP. 0b013e31820918cb)

Sakaguchi H, Fujimoto J, Aoki I \& Tamaya T 2003 Expression of estrogen receptor $\alpha$ and $\beta$ in myometrium of premenopausal and postmenopausal women. Steroids 68 11-19. (doi:10.1016/S0039128X(02)00111-3)

Schlecht C, Klammer H, Wuttke W \& Jarry H 2006 A dose-response study on the estrogenic activity of benzophenone- 2 on various endpoints in the serum, pituitary and uterus of female rats. Archives of Toxicology $\mathbf{8 0}$ 656-661. (doi:10.1007/s00204-006-0085-1)

Schoeters G, Den Hond E, Dhooge W, van Larebeke N \& Leijs M 2008 Endocrine disruptors and abnormalities of pubertal development. Basic Clinical Pharmacology \& Toxicology 102 168-175. (doi:10.1111/ j.1742-7843.2007.00180.x)

Setiawan VW, Yang HP, Pike MC, McCann SE, Yu H, Xiang YB, Wolk A, Wentzensen N, Weiss NS, Webb PM et al. 2013 Type I and II endometrial cancers: have they different risk factors? Journal of Clinical Oncology 31 2607-2618. (doi:10.1200/JCO.2012.48.2596)

Shelby MD, Newbold RR, Tully DB, Chae K \& Davis VL 1996 Assessing environmental chemicals for estrogenicity using a combination of in vitro and in vivo assays. Environmental Health Perspectives 104 1296-1300. (doi:10.1289/ehp.961041296)

Sierens JE, Scobie GA, Wilson J \& Saunders PT 2004 Cloning of oestrogen receptor $\beta$ from Old and New World primates: identification of splice variants and functional analysis. Journal of Molecular Endocrinology 32 703-718. (doi:10.1677/jme.0.0320703)

Simpson ER 2003 Sources of estrogen and their importance. Journal of Steroid Biochemistry and Molecular Biology 86 225-230. (doi:10.1016/ S0960-0760(03)00360-1)

Smith CC \& Taylor HS 2007 Xenoestrogen exposure imprints expression of genes (Hoxa10) required for normal uterine development. FASEB Journal 21 239-246. (doi:10.1096/fj.06-6635com)

Sturgeon SR, Brock JW, Potischman N, Needham LL, Rothman N, Brinton LA \& Hoover RN 1998 Serum concentrations of organochlorine compounds and endometrial cancer risk (United States). Cancer Causes \& Control 9 417-424. (doi:10.1023/A:1008823802393)

Stygar D, Wang H, Vladic YS, Ekman G, Eriksson H \& Sahlin L 2001 Co-localization of oestrogen receptor $\beta$ and leukocyte markers in the human cervix. Molecular Human Reproduction 7 881-886. (doi:10.1093/ molehr/7.9.881)

Sui Y, Ai N, Park SH, Rios-Pilier J, Perkins JT, Welsh WJ \& Zhou C 2012 Bisphenol $\mathrm{A}$ and its analogues activate human pregnane $\mathrm{X}$ receptor. Environmental Health Perspectives 120 399-405. (doi:10.1289/ehp. 1104426)

Sun J, Meyers MJ, Fink BE, Rajendran R, Katzenellenbogen JA \& Katzenellenbogen BS 1999 Novel ligands that function as selective estrogens or antiestrogens for estrogen receptor- $\alpha$ or estrogen receptorß. Endocrinology 140 800-804. (doi:10.1210/en.140.2.800)

Takayanagi S, Tokunaga T, Liu X, Okada H, Matsushima A \& Shimohigashi Y 2006 Endocrine disruptor bisphenol A strongly binds to human estrogen-related receptor $\gamma(\mathrm{ERR} \gamma)$ with high constitutive activity. Toxicology Letters 167 95-105. (doi:10.1016/j.toxlet.2006.08.012)

Tamae D, Byrns M, Marck B, Mostaghel EA, Nelson PS, Lange P, Lin D, Taplin ME, Balk S, Ellis W et al. 2013 Development, validation and 
application of a stable isotope dilution liquid chromatography electrospray ionization/selected reaction monitoring/mass spectrometry (SID-LC/ESI/SRM/MS) method for quantification of keto-androgens in human serum. Journal of Steroid Biochemistry and Molecular Biology 138C 281-289. (doi:10.1016/j.jsbmb.2013.06.014)

Tantamango-Bartley Y, Jaceldo-Siegl K, Fan J \& Fraser G 2013 Vegetarian diets and the incidence of cancer in a low-risk population. Cancer Epidemiology, Biomarkers \& Prevention 22 286-294. (doi:10.1158/ 1055-9965.EPI-12-1060)

Taylor AH \& Al-Azzawi F 2000 Immunolocalisation of oestrogen receptor $\beta$ in human tissues. Journal of Molecular Endocrinology 24 145-155. (doi:10.1677/jme.0.0240145)

Taylor HS, Vanden Heuvel GB \& Igarashi P 1997 A conserved Hox axis in the mouse and human female reproductive system: late establishment and persistent adult expression of the Hoxa cluster genes. Biology of Reproduction 57 1338-1345. (doi:10.1095/biolreprod57.6.1338)

Teng C, Goodwin B, Shockley K, Xia M, Huang R, Norris J, Merrick BA, Jetten AM, Austin CP \& Tice RR 2013 Bisphenol A affects androgen receptor function via multiple mechanisms. Chemico-Biological Interactions 203 556-564. (doi:10.1016/j.cbi.2013.03.013)

Thomas CC, Wingo PA, Dolan MS, Lee NC \& Richardson LC 2009 Endometrial cancer risk among younger, overweight women. Obstetrics and Gynecology 114 22-27. (doi:10.1097/AOG.0b013e3181ab6784)

Tinwell H \& Ashby J 2004 Sensitivity of the immature rat uterotrophic assay to mixtures of estrogens. Environmental Health Perspectives 112 575-582. (doi:10.1289/ehp.6831)

Tinwell H, Joiner R, Pate I, Soames A, Foster J \& Ashby J 2000 Uterotrophic activity of bisphenol A in the immature mouse. Regulatory Toxicology and Pharmacology 32 118-126. (doi:10.1006/rtph.2000.1412)

Troisi R, Hatch EE, Titus-Ernstoff L, Hyer M, Palmer JR, Robboy SJ, Strohsnitter WC, Kaufman R, Herbst AL \& Hoover RN 2007 Cancer risk in women prenatally exposed to diethylstilbestrol. International Journal of Cancer 121 356-360. (doi:10.1002/ijc.22631)

Unfer V, Casini ML, Costabile L, Mignosa M, Gerli S \& Di Renzo GC 2004 Endometrial effects of long-term treatment with phytoestrogens: a randomized, double-blind, placebo-controlled study. Fertility and Sterility 82 145-148 quiz 265. (doi:10.1016/j.fertnstert.2003.11.041)

Varayoud J, Ramos JG, Bosquiazzo VL, Lower M, Munoz-de-Toro M \& Luque EH 2011 Neonatal exposure to bisphenol A alters rat uterine implantation-associated gene expression and reduces the number of implantation sites. Endocrinology 152 1101-1111. (doi:10.1210/ en.2009-1037)
Vasiliu O, Muttineni J \& Karmaus W 2004 In utero exposure to organochlorines and age at menarche. Human Reproduction 19 1506-1512. (doi:10.1093/humrep/deh292)

Vuorinen A, Odermatt A \& Schuster D 2013 In silico methods in the discovery of endocrine disrupting chemicals. Journal of Steroid Biochemistry and Molecular Biology 137 18-26. (doi:10.1016/ j.jsbmb.2013.04.009)

Walker DM, Kermath BA, Woller MJ \& Gore AC 2013 Disruption of reproductive aging in female and male rats by gestational exposure to estrogenic endocrine disruptors. Endocrinology 154 2129-2143. (doi:10.1210/en.2012-2123)

Wallace AE, Gibson DA, Saunders PT \& Jabbour HN 2010 Inflammatory events in endometrial adenocarcinoma. Journal of Endocrinology 206 141-157. (doi:10.1677/JOE-10-0072)

Warner M, Samuels S, Mocarelli P, Gerthoux PM, Needham L, Patterson DG Jr \& Eskenazi B 2004 Serum dioxin concentrations and age at menarche. Environmental Health Perspectives 112 1289-1292. (doi:10.1289/ehp.7004)

Watanabe H, Suzuki A, Goto M, Lubahn DB, Handa H \& Iguchi T 2004 Tissue-specific estrogenic and non-estrogenic effects of a xenoestrogen, nonylphenol. Journal of Molecular Endocrinology 33 243-252. (doi:10.1677/jme.0.0330243)

Weiderpass E \& Baron JA 2001 Cigarette smoking, alcohol consumption, and endometrial cancer risk: a population-based study in Sweden. Cancer Causes \& Control 12 239-247. (doi:10.1023/A:1011201911664)

Weiderpass E, Adami HO, Baron JA, Wicklund-Glynn A, Aune M, Atuma S \& Persson I 2000 Organochlorines and endometrial cancer risk. Cancer Epidemiology, Biomarkers \& Prevention 9 487-493.

Wormke M, Castro-Rivera E, Chen I \& Safe S 2000 Estrogen and aryl hydrocarbon receptor expression and crosstalk in human Ishikawa endometrial cancer cells. Journal of Steroid Biochemistry and Molecular Biology 72 197-207. (doi:10.1016/S0960-0760(00)00030-3)

$\mathrm{Wu}$ JJ, Geimonen E \& Andersen J 2000 Increased expression of estrogen receptor $\beta$ in human uterine smooth muscle at term. European Journal of Endocrinology/European Federation of Endocrine Societies 142 92-99. (doi:10.1530/eje.0.1420092)

Yamasaki K, Sawaki M \& Takatsuki M 2000 Immature rat uterotrophic assay of bisphenol A. Environmental Health Perspectives 108 1147-1150. (doi:10.1289/ehp.001081147)

Zang H, Sahlin L, Masironi B, Eriksson E \& Linden Hirschberg A 2007 Effects of testosterone treatment on endometrial proliferation in postmenopausal women. Journal of Clinical Endocrinology and Metabolism 92 2169-2175. (doi:10.1210/jc.2006-2171)

Received in final form 15 October 2013

Accepted 23 October 2013

Made available online as an Accepted Preprint

25 October 2013 http://erc.endocrinology-journals.org

DOI: 10.1530/ERC-13-0342
(C) 2014 Society for Endocrinology Printed in Great Britain 